\title{
Local Circuitry of Identified Projection Neurons in Cat Visual Cortex Brain Slices
}

\author{
Lawrence C. Katz \\ Division of Biology, California Institute of Technology, Pasadena, California 91125
}

The relationship between pyramidal cell morphology and efferent target was investigated in layer 6 of cat primary visual cortex (area 17). Layer 6 has 2 projections, one to the lateral geniculate nucleus (LGN) and another to the visual claustrum. The cells of origin of each projection were identified by retrograde transport of fluorescent latex microspheres. The labeled cells were visualized in brain slices prepared from area 17 , using an epifluorescence compound microscope modified for intracellular recording. Individual retrogradely labeled cells were penetrated and intracellularly stained with Lucifer yellow to visualize the patterns of axons and dendrites associated with each projection.

The neurons that give rise to the 2 projections had very different patterns of dendrites and local axonal collaterals, but the patterns within each group were highly stereotyped. The differences between their axonal collaterals were particularly dramatic. Claustrum projecting cells had fine, horizontally directed collaterals that arborized exclusively in layer 6 and lower layer 5. Most LGN projecting cells had virtually no horizontal arborization in layer 6 . Instead, they sent widespread collaterals vertically, which arborized extensively in layer 4. The apical dendrites of the 2 groups also differed markedly. Claustrum projecting cells had apical dendrites reaching to layer 1, with branches in layer 5 only, while LGN projecting cells never had an apical dendrite reaching higher than layer 3 , with side branches in layers 5 and 4 . Therefore, each efferent target must receive inputs from neurons whose synaptic connections within area 17 are significantly different from those of neurons projecting to other targets. This further suggests that distinct visual response properties should be associated with each projection.

In addition to the claustrum and LGN projecting cells, about $20 \%$ of layer 6 pyramidal neurons lacked an efferent axon. Morphologically, most resembled LGN projecting neurons,

\footnotetext{
Received Aug. 5, 1986; revised Sept. 28, 1986; accepted Oct. 2, 1986.

I am most grateful to Dr. Mark Konishi, who so generously supported and encouraged this work. Dr. T. Wiesel provided invaluable critical advice on the manuscript. I would also like to thank everyone who provided many useful comments: Drs. M. Constantine-Paton, C. Gilbert, C. Mason, B. McGuire, and I. Naegele. Special thanks to Herb Adams, Senior Instrument Designer at Caltech, for his expert design and fabrication of critical pieces of equipment, to Dr. Jack Pettigrew, who brought the experimental advantages of layer 6 to my attention, and to Peter Peirce for photography. These experiments were made possible largely by grants from the Caltech President's Venture Fund and the NIH Biomedical Research Support Grant Program (RR07003). Also supported by NSF and NIH predoctoral fellowships (35 T32 GM07737-05).

Correspondence should be addressed to Lawrence C. Katz, Neurobiology Laboratory, Box 138, The Rockefeller University, 1230 York Avenue, New York, NY 10021.
}

Copyright (C) 1987 Society for Neuroscience 0270-6474/87/041223-27\$02.00/0 but a few had characteristics of claustrum projecting cells. These neurons may represent cells that either failed to make an efferent connection or cells that lost an efferent axon during development. Their frequency suggests that such intrinsic, presumably excitatory, neurons may play a significant role in cortical processing.

The laminatcd pattern of mammalian neocortex has provided an essential framework for anatomical and physiological investigations of all cortical areas and of the primary visual cortex in particular. Cells in each cortical layer share properties that are either absent or rare in other layers. Anatomical studies recognized that individual layers could be distinguished not only by cell size and density, but also by unique morphological cell types (e.g., Cajal, 1911; Lorente de No, 1933; Lund, 1973, 1981; Jones, 1975; Lund et al., 1979). Physiological studies demonstrated that cells within each lamina shared many receptive field properties and that these responses clearly differed across layers (Hubel and Wiesel, 1962; Palmer and Rosenquist, 1974; Toyama et al., 1974; Singer et al., 1975; Gilbert, 1977; Leventhal and Hirsch, 1978; Tsumoto et al., 1978; Henry et al., 1979; Harvey, 1980).

However, along with their common properties, neurons within the same layer also cxpress numcrous morphological and physiological differences. Golgi studies have identified numerous varieties of pyramidal cells in each lamina; for example, Lund and Boothe (1975) defined 4 types of monkey layer 6 pyramidal cells, based on specific differences in the branching patterns of their apical dendrites, and Lund et al. (1985) uncovered 8 distinct varieties of layer 6 cells in tree shrew striate cortex. Physiologically, cells within each layer exhibit a similarly wide range of visual responses; cat layer 6 , for example, contains monocular and binocular cells, simple and complex cells, cells with long and short receptive fields, and direction and nondirection selective cells (Gilbert, 1977; Harvey, 1980; Tsumoto and Suda, 1980; Ferster and Lindström, 1983). So far, intracellular recording and staining have revealed few general, systematic rules for relating the detailed structural and physiological diversity among cortical cells within a layer (Kelly and Van Essen, 1974; Gilbert and Wiesel, 1979, 1983; Martin, 1984; Martin and Whitteridge, 1984). Uncovering these rules remains vital to understanding how the striate cortex manipulates and transforms incoming visual information.

In addition to the diversity of neuronal forms and receptive field properties, pyramidal neurons within a single layer connect a number of distinct targets, either intra- or subcortical (reviewed in Gilbert, 1983; Rosenquist, 1985). Cells in layer 3 of the cat, for example, send axons to as many as 7 extrastriate 
cortical areas (Tusa et al., 1981; Rosenquist, 1985). In general, each pyramidal cell connects to only a single target, but no obvious features, such as cell body size, distinguish neighboring cells that project to one target from those projecting to another.

Analogy with the organization of the mammaliam retina suggests that multiple projections from single layers could represent the output of different local circuits performing distinct types of visual analysis. In the cat retina, the somata of On- and Offcenter ganglion cells reside in one layer, but their dendrites arborize in different strata within the overlying synaptic layer. There they receive input from different local circuit neurons (Famiglietti and Kolb, 1976). In the ferret and mink, these 2 ganglion cell types also project to physically and functionally distinct layers in the lateral geniculate nucleus (LGN) (LeVay and McConnell, 1982). In these retinae, then, a neuron's shape is associated with the output of a local circuit, a visual response property, and a single efferent projection.

The experiments described here ask whether, as in the retina, morphological diversity in a cortical layer is linked to that layer's multiple projection targets. If cortex and retina use similar organizing principles, then pyramidal cells projecting to the same target should have similar dendritic arbors, reflecting a stereotyped pattern of synaptic input. They should also have similar laminar patterns of intrinsic axonal arborizations, reflecting participation in common local circuits. Alternatively, if a given target samples the outputs of many of the circuits within a layer, then the group of pyramidal cells projecting to a single target should contain neurons of many different morphological types.

Layer 6 of cat striate cortex provided an excellent opportunity for testing whether a specific projection and a distinct neuronal morphology could be related. Two subcortical projections, to the visual claustrum and to the LGN, arise from different, but intermingled populations of layer 6 pyramidal cells (LeVay and Sherk, 1981a). Resolving the relationship between neuronal structure and projection target required methods for (1) reliably identifying a neuron's target and (2) revealing the cell's dendritic and axonal arbors. These requirements were met by combining and modifying several anatomical and physiological techniques. Injections of a retrogradely transported fluorescent tracer into either the claustrum or LGN identified the different populations of layer 6 projection neurons. These were visualized, using fluorescence microscopy, in living brain slices of cat striate cortex. Subsequent intracellular injections of retrogradely labeled cells with a second fluorescent dye allowed direct characterization and comparison of the laminar distribution of axons and dendrites of cells identified by their efferent projection. An abbreviated report of some of these investigations has appearred previously (Katz et al., 1984).

\section{Materials and Methods}

Fifteen adult cats of both sexes $(2.5-4.5 \mathrm{~kg})$ were used in these experiments. For all surgical procedures cats were anesthetized with Nembutal ( $40 \mathrm{mg} / \mathrm{kg}$, i.p., initial dose, supplemented as required) and placed in a conventional stereotaxic frame. During electrophysiological recording sessions, cats had their nictitating membranes retracted with Neosynephrine (2.5\%, Winthrop), pupils dilated with atropine (1\%, $\mathrm{Al}-$ con), and corneas protected with zero-power contact lenses. An electric heating blanket maintained body temperature. Animals that were to recover received a prophylactic dose of $0.5 \mathrm{cc}$ of penicillin postoperatively.

The LGN was located using standard stereotaxic and extracellular electrophysiological techniques. The receptive fields of either single units or small groups of cclls ncar the dorsal surface of the nuclcus were mapped onto a tangent screen with a small spot of light (about $1^{\circ} \mathrm{di}$ ameter) from a hand-held projector. This provided the approximate position of the electrode in the LGN, according to the map of Sanderson (1971). The recording electrode was then replaced with a $1 \mu$ l glasstipped Hamilton syringe filled with the retrograde tracer, a suspension of fluorescent red latex microspheres (Katz et al., 1984). A total of six $1 \mu 1$ injections were then made in a grid pattern; injections were separated by at least $1 \mathrm{~mm}$ and involved all geniculate laminae.

Tracer injections into the claustrum followed the same basic procedure. The claustrum was located using the procedure described by LeVay and Sherk (1981a) and received 2 or $31 \mu \mathrm{l}$ microsphere injections, spaced about $500 \mu \mathrm{m}$ apart.

Slice preparation. All experiments used $400-\mu \mathrm{m}$-thick coronal slices of cat arca 17. Cats with previous tracer injections were reanesthetized with Nembutal, and a large craniotomy was performed, followed by retraction of the dura overlying 1 hemisphere. A large section of posterior cortex was removed by making deep scalpel cuts around area 17, undercutting the white matter, and removing the brain section with a Teflon spatula. This section was immediately placed in a beaker of $15^{\circ} \mathrm{C}$ artificial cerebrospinal fluid [ACSF; composition (in $\mathrm{mM}$ ): $\mathrm{NaCl} 124$, $\mathrm{KCl} 5, \mathrm{KH}_{2} \mathrm{PO}_{4} 1.25, \mathrm{MgSO}_{4} 2, \mathrm{CaCl}_{2} 3, \mathrm{NaHCO}_{3} 26, d$-glucose 10 , $\mathrm{pH}$ 7.4] and then trimmed with razor blades to form a block about 2 $\mathrm{cm}$ long, $1 \mathrm{~cm}$ wide, and $0.8 \mathrm{~cm}$ thick. The pia was gently stripped off using fine forceps. The block was then placed on a $5 \mathrm{~mm}$ thick agar slab ( $2 \%$ Difco Bactero-Agar in ACSF) on the stage of a slicing apparatus (Fig. 1A) designed to make slices of large pieces of brain rapidly and accurately. In principle, the device resembles a kitchen egg slicer (Fig. $1 B$ ). A spring-loaded arm holds a removable stainless steel cutting grid. The grid has a rectangular opening, $25 \mathrm{~mm}$ by $13 \mathrm{~mm}$, across which are tightly stretched a series of 60 parallel, gold-plated tungsten wires, $20 \mu \mathrm{m}$ in diameter, $400 \mu \mathrm{m}$ apart (Fig. 1C). Pressing a trigger releases the arm, causing the thin wires of the grid to cut through the brain and the agar pad at high velocity. This produces precise, $400-\mu \mathrm{m}$-thick slices, without visible brain compression or deformation. The slicer can prepare up to 60 viable slices in a single rapid operation.

The sliced tissue was transferred to a petri dish filled with $15^{\circ} \mathrm{C}$ oxygenated ACSF, where slices were gently separated with fine paintbrushes. Individual slices were floated onto $6 \times 8 \mathrm{~mm}$ rectangles of embedding bag paper (Spectrum) and placed 6 to a well in a 4-well hippocampal slice chamber similar to that described in Hatton et al. (1980). Polycarbonate filter membrane $(12 \mu \mathrm{m}$ pore size, Nucleopore Corp., Plcasanton, CA), whose smooth surface facilitated removing slices for transfer to the recording apparatus, replaced the standard nylon mesh slice supports. A temperature probe/feedback circuit kept the chamber at $33^{\circ} \mathrm{C}$; a warmed, humidified mixture of $95 \% \mathrm{O}_{2}, 5 \% \mathrm{CO}_{2}$, flowing at approximately $175 \mathrm{ml} / \mathrm{min}$, provided oxygenation. Slices remained viable for up to $16 \mathrm{hr}$. The entire slicing operation, from brain removal to placement in the holding chamber, usually took less than 15 min per hemisphere.

After removal of both hemispheres, the cat was perfused intracardially with $0.1 \mathrm{M}$ phosphate buffer, followed by $10 \%$ formalin in $0.1 \mathrm{M}$ phosphate buffer. For verification of injection sites, appropriate portions of the brain were blocked, sunk in $30 \%$ sucrose in $0.1 \mathrm{M}$ phosphate buffer, and sectioned at $40 \mu \mathrm{m}$ on a freezing microtome. Sections were mounted on gelatin-subbed slides, air-dried, cleared in xylene for 1-2 min, and coverslipped using Fluoromount (Gurr).

Intracellular recording and labeling. After a recovery time of at least $1.5 \mathrm{hr}$, individual slices were transferred from the holding chamber to a chamber on the stage of a modified epifluorescence-equipped Zeiss WL compound microscope. A $16 \times$ objective (N.A. 0.35), heating to about $35^{\circ} \mathrm{C}$ to prevent condensation, fit through a hole in the chamber's sliding cover.

In early experiments, conventional glass microelectrodes were pulled on a Brown-Flaming micropipette puller (Sutter Instruments) from 1.2 $\mathrm{mm}$ O.D. Omega dot tubing (Frederick Haer Co.), and filled with $20 \%$ Lucifer yellow (Aldrich) in $0.1 \mathrm{M} \mathrm{LiCl}$ (Stewart, 1978). These electrodes were advanced through the slice with a hydraulic microdrive, at about a $20^{\circ}$ angle, in regions of retrogradely labeled cell bodies. Cells were intracellularly filled at random, yielding "double labeled" cells [containing retrogradcly transported microsphercs and intracellularly injected Lucifer yellow (Fig. 2C)] directly proportional to the number of retrogradely labeled cells (about $50 \%$ for the LGN projection and about $5 \%$ for the claustrum projection). In later experiments, the tip of each microelectrode was bent to about $90^{\circ}$ (Hudspeth and Corey, 1978), 

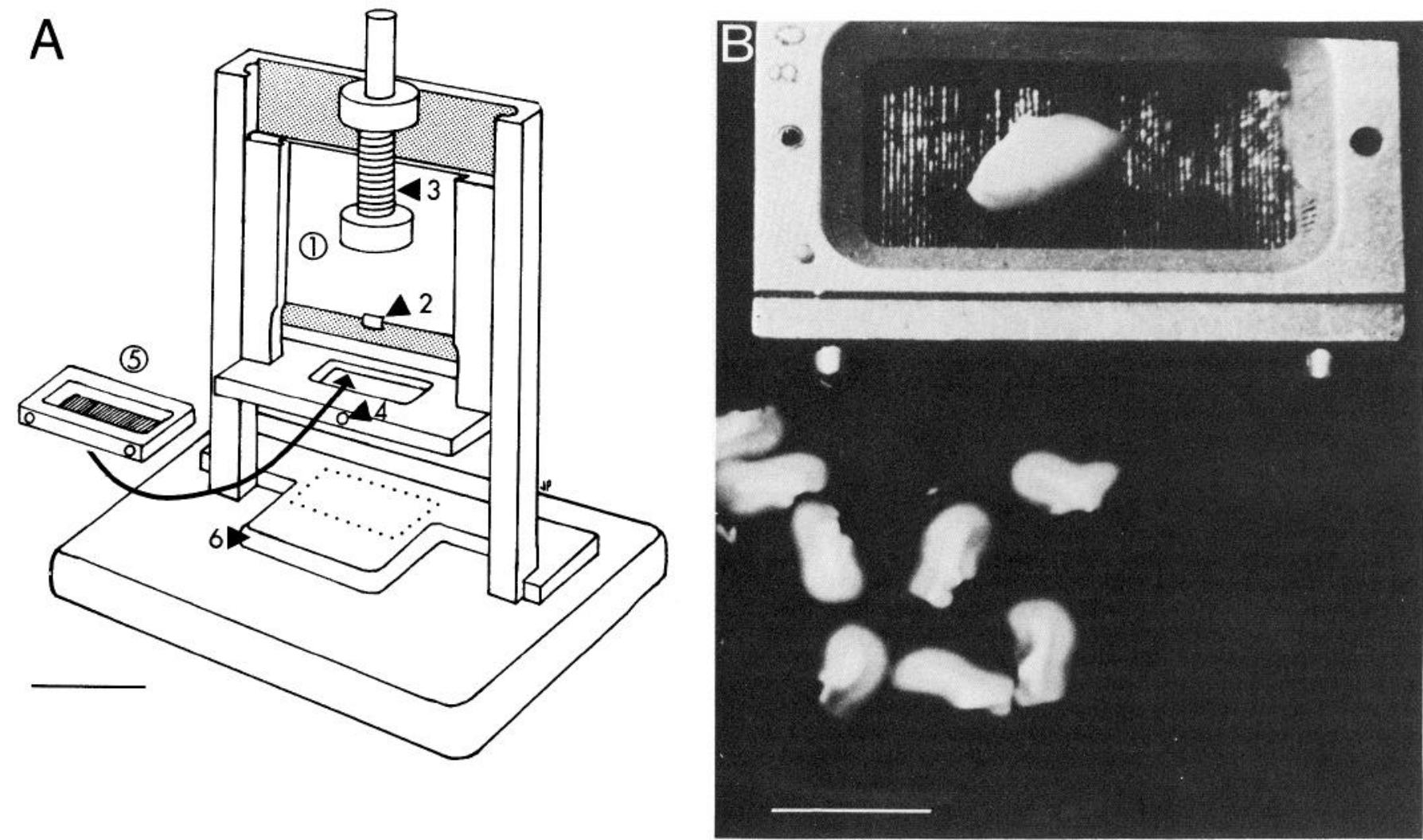

Figure 1. The brain slicer. A, Drawing of the slicer in "loaded" position. A spring-driven sliding arm (I) is held by a catch (2). A removable cutting grid (5), consisting of fine wires, fits into a recess in the sliding arm, as shown by the arrow. When a trigger (not shown) at the rear of the slicer releases the sliding arm, the spring (3) propels the grid through the tissue, which sits on an agar pad in the outlined area. After slicing, the grid is released by loosening the grid lock screw (4), the sliding arm is returned to the loaded position, and the cutting grid and sliced tissue are transferred from the apparatus to a petri dish, using the removable base plate (6). Scale bar, $3 \mathrm{~cm}$. B, The upper portion of the photograph shows a piece of visual cortex just sliced (in the coronal plane) by the tissue slicer; the fine gold wires of the cutting grid are visible. In the lower portion of the field, separated slices await transfer to the holding chamber. Scale bar, $1 \mathrm{~cm}$.

permitting penetrations normal to the surface of the slice. This allowed an electrode to be "aimed" at a particular retrogradely labeled cell body. Both modified and unmodified electrodes had initial resistances of approximately $350 \mathrm{M} \Omega$; the tips were usually manually broken to a final resistance of 100-200 M . The tip of a bent electrode was aligned with retrogradely labeled cell bodies by means of an eyepiece graticule and advanced through the slice in 1-3 $\mu \mathrm{m}$ steps with the fine vertical control on a Leitz micromanipulator. Standard electronics amplified and displayed intracellular electrical activity. Cells were penetrated by applying $90 \mathrm{~V}$ positive voltage pulses, $200 \mathrm{msec}$ long, to the electrode. Stable cells, generally with action potentials of at least $40 \mathrm{mV}$ and less than 1 msec duration at half-height, were injected with Lucifer yellow using trapezoidal current pulses $(10 \mathrm{msec}$ rise/fall time, $200 \mathrm{msec}$ duration, $4 \mathrm{~Hz}, 2.5 \mathrm{nA}$, electrode negative) for 1-10 min, usually until anode break action potentials and resting potential disappeared. After filling 4-6 cells, the slice was removed from the chamber and fixed in $10 \%$ formalin in $0.1 \mathrm{M}$ phosphate buffer. After fixation ( $24 \mathrm{hr}-6$ months), individual slices were immersed in $30 \%$ sucrose in $0.1 \mathrm{M}$ phosphate buffer until they sank; they were then sectioned parallel to the sliced surfaces at $60 \mu \mathrm{m}$ on a freezing microtome. Sections were mounted on gelatin-subbed slides, air-dried, briefly heated on a slide warmer, cleared directly in xylene for 1-2 min, coverslipped with Fluoromount (Gurr), and examined and photographed on a Zeiss Standard WL epifluorescence microscope with rhodamine and fluorescein filters. Drawings of selected Lucifer yellow-stained cells were made with a $100 \times$ oil-immersion objective (N.A. 1.0) and a camera lucida (final magnification, $1250 \times$ ) on black paper with white pencils. All photography was done with Kodak ASA 200 Ektachrome film.

Measurements of distances between labeled neurons in vitro (at $160 \times$ ) and after processing showed no shrinkage within the limits of measurements; thus, shrinkage in the plane of the section was under $5 \%$.
Shrinkage orthogonal to the plane of slicing was not assessed, since all reconstructions were 2 dimensional. No corrections, therefore, were made for tissue shrinkage in any of the data presented below.

Laminar and areal boundaries were delineated according to the criteria of Otsuka and Hassler (1962). Nomarski-differential-interference contrast optics provided a fairly reliable indication of laminar boundaries in uncounterstained sections, but for precise determination of boundaries, sections were subsequently counterstained with cresyl violet. This procedure destroyed the microspheres' fluorescence, but the Lucifer yellow fluorescence persisted quite well.

Measurements of axon and soma sizes. Camera lucida drawings of retrogradely labeled cell somata (drawn using a $100 \times$ oil-immersion objective, N.A. 1.0, at a final magnification of $1250 \times$ ) were entered via a digitizing tablet into a computer (Hewlett-Packard 2647 graphics terminal), which calculated somatal area. Since axons were usually too thin to measure directly using an eyepiece graticule, estimates of axon diameters were obtained by photographing portions of the axon with a $100 \times$ objective and measuring the diameter of the photographic image using a compound microscope with a $10 \times$ objective and eyepiece graticule. The resolution of this system was probably no better than $0.3 \mu \mathrm{m}$.

Fluorescent latex microspheres: characteristics as an in vitro retrograde tracer. The properties of fluorescent microspheres as a marker in conventional retrograde tracing studies have been described previously (Katz et al., 1984). Microspheres offer several advantages over other fluorescent tracers in the kinds of experiments described in this report. They do not leak or diffuse out of cells, even after very long survival times, after the manipulations involved in preparing slices, or following prolonged storage of slices after an experiment. This assures that cells labeled with microspheres did in fact project to the appropriate site. Illumination of microspheres does not seem toxic to cells, which contrasts with the marked phototoxicity of many fluorescent dyes [e.g., 

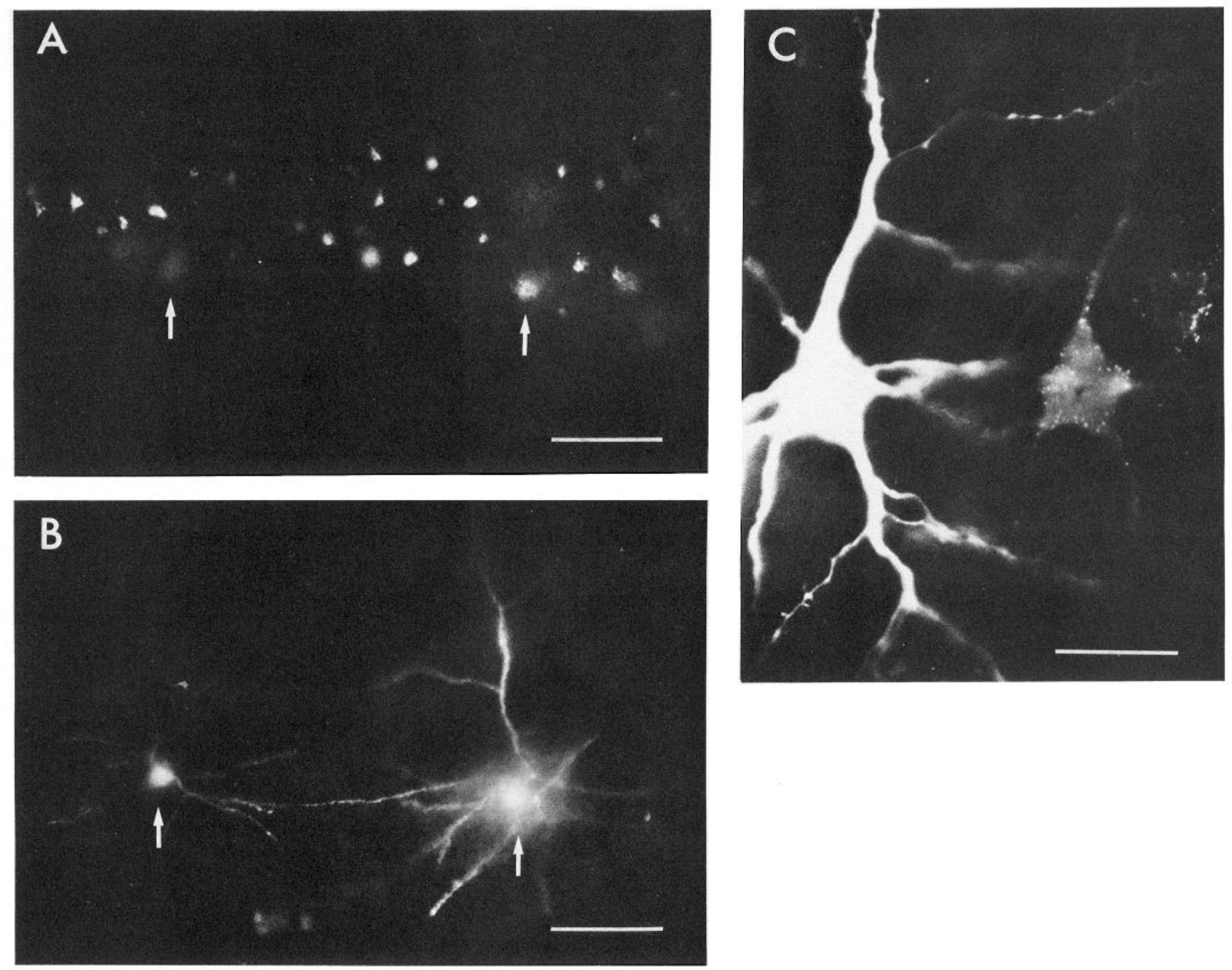

Figure 2. Combination of retrograde and intracellular labeling in slices. $A$, Neuronal cell bodies in a living brain slice, retrogradely labeled with microspheres, following injection of the visual claustrum. In this $400-\mu \mathrm{m}$-thick section, less than $5 \%$ of the cell bodies are labeled. Arrows indicate the out-of-focus cell bodies double-labeled with Lucifer yellow, shown in $B$. B. Same field as $A$ seen under Lucifer yellow illumination wavelengths, showing 2 claustrum projecting cells intracellularly injected. The somata, dendrites, and even dendritic spines are visible. Scale bars, $100 \mu \mathrm{m}$. $C$, Claustrum projecting neuron double-labeled by retrogradely transported microspheres and intracellularly injected Lucifer yellow. The exposure at right was made under rhodamine illumination, the section was then shifted slightly, and the exposure at left was made, under Lucifer yellow illumination. The background haze in the microsphere exposure results from weak fluorescence of Lucifer yellow at rhodamine wavelengths. Scale bar, $20 \mu \mathrm{m}$.

Lucifer yellow (Miller and Selverston, 1979)] and probably relates to the fact that microspheres show very little bleaching under illumination (Gupta et al., 1981). The fluorescent intensity of microsphere-labeled cells allows labeled neurons to be easily visualized in uncleared, thick slices at relatively low magnification, thereby facilitating "aiming" for specific cells.

\section{Results}

Under epifluorescence illumination, neurons retrogradely labeled with microspheres were clearly visible in living brain slices of the cat visual cortex. Although the aqueous environment degraded image quality, the microspheres outlined the pyramidal shape of cell bodies in about the top $200 \mu \mathrm{m}$ of the slices with a brilliant red, granular fluorescence (Fig. 2). Consequently, penetrating selected retrogradely labeled cells with bent electrodes was quite successful; in healthy preparations the intended cell was impaled in about $75 \%$ of attempts. This yielded representative samples of even the relatively rare claustrum projecting cells, since frequently 40 cells were successfully stained in an experiment. Both microsphere-labeled and unlabeled cells appeared equally healthy; both types of cells generally had action potentials of $45-70 \mathrm{mV}$ (with $0.1 \mathrm{M} \mathrm{LiCl} / \mathrm{Lucifer}$ yellow electrodes) and resting potentials of -50 to $-60 \mathrm{mV}$. Penetrations were generally stable (no loss of action or resting potentials) for 5-30 min. Action potentials of claustrum and LGN projecting neurons were also indistinguishable at this level of analysis.

An example of retrogradely and intracellularly labeled cells in vitro is shown in Figure 2. The somata, dendrites, and occasionally the axons of intracellularly filled neurons were readily discernible; the clarity of these features depended greatly on the depth of the labeled cell in the slice. Although double-labeled 

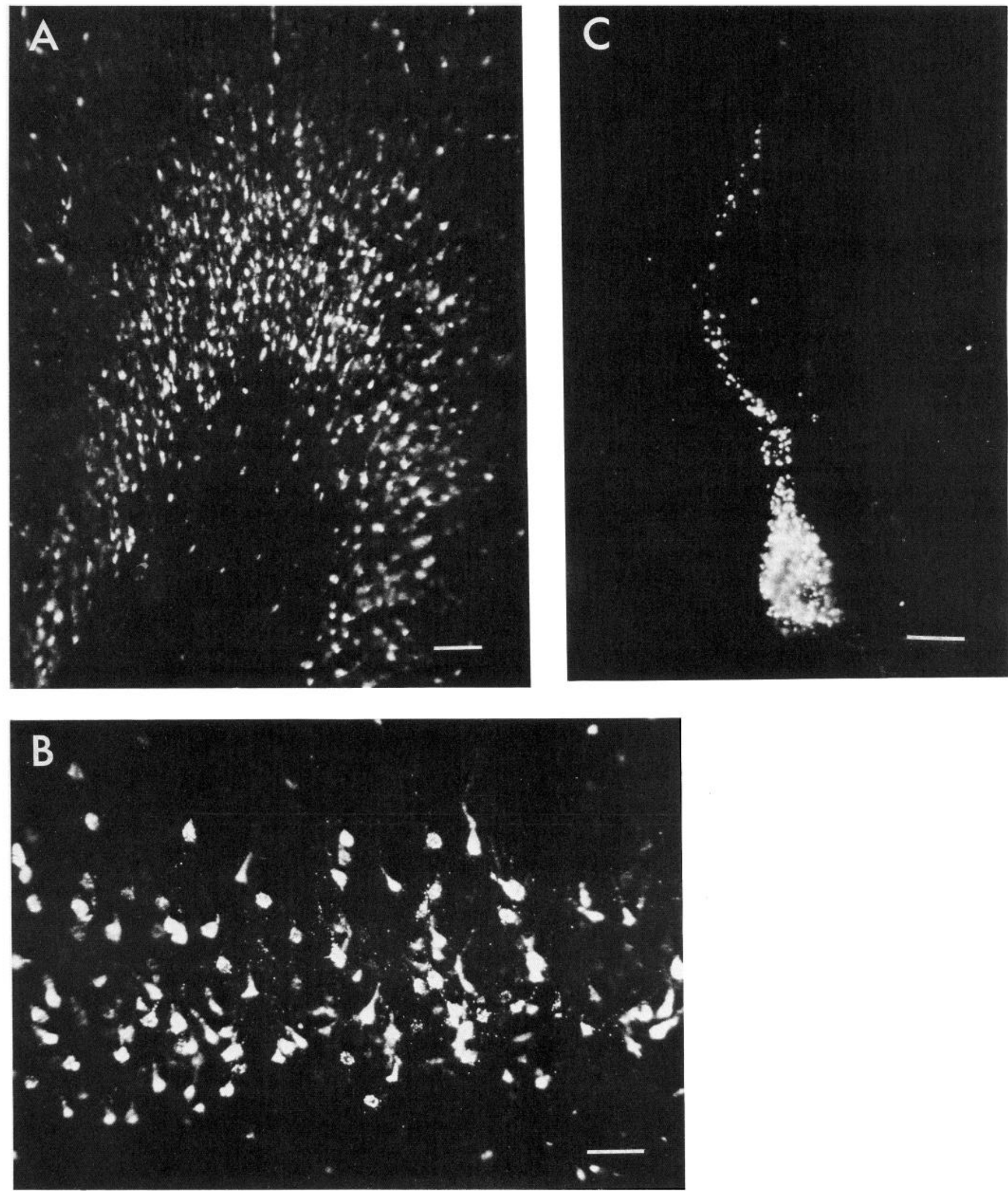

Figure 3. Retrograde labeling of the LGN projecting neurons in area 17. A, Microsphere labeling at the apex of the lateral gyrus following LGN injections. The occasional bright spots in the white matter and outside layer 6 are artifacts. Scale bar, $100 \mu \mathrm{m}$. $B$, Higher-power view of retrogradely labeled neurons, mostly medium-sized pyramidal cells, located throughout the thickness of layer 6 . Scale bar, $50 \mu \mathrm{m}$. $C$, Single retrogradely labeled pyramidal cell, with a soma and apical dendrite densely packed with granular appearing microspheres. Scale bar, $10 \mu \mathrm{m}$. 


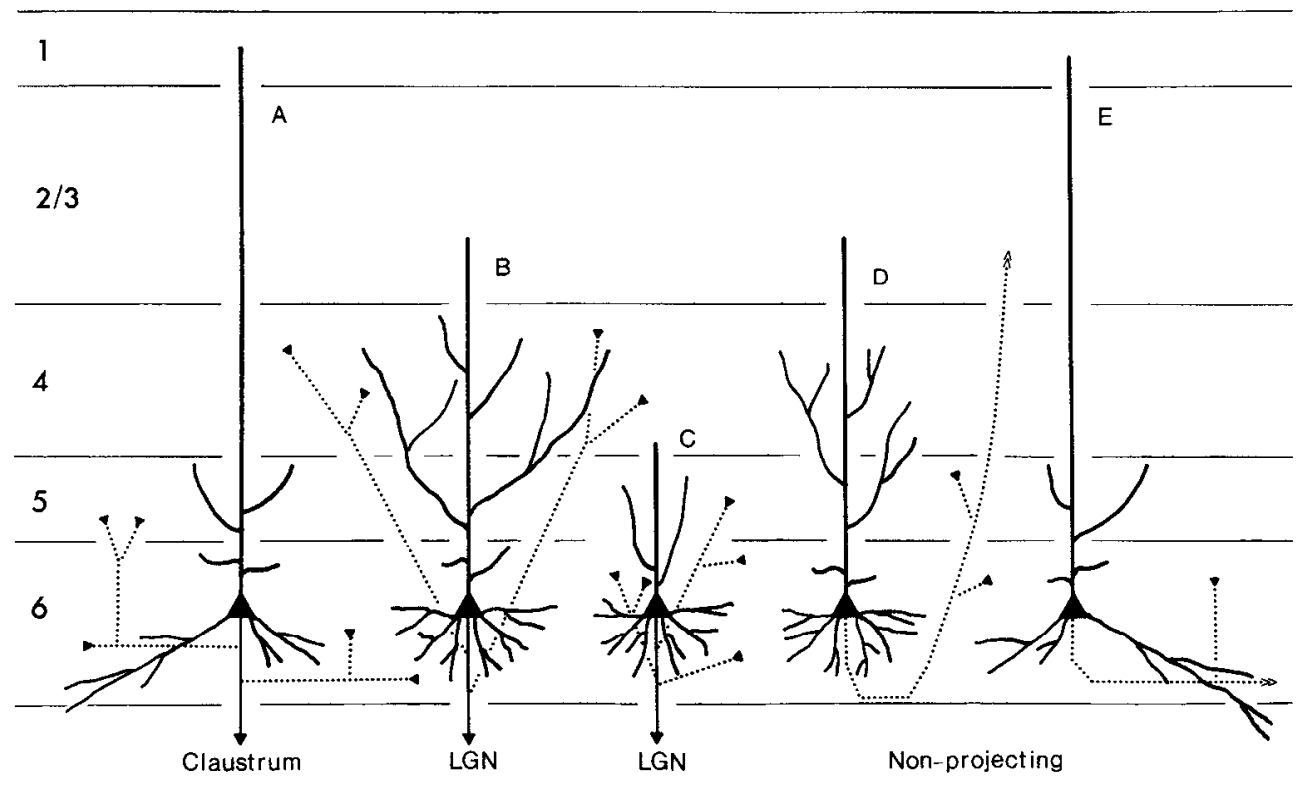

Figure 4. Schematic illustration of the dendritic and axonal arborizations of the major cell types described in this report. Solid lines and arrows indicate site of efferent projection, dotted lines indicate paths of intrinsic axons, the triangles on their ends represent synaptic terminals, the double arrowheads indicate that the collaterals could not be followed to their final termination site. $A$, Claustrum projecting neuron; $B$, type I lateral geniculate nucleus projecting neuron; $C$, type II LGN projecting neuron; $D$, LGN-type intrinsic pyramidal cell; $E$, claustrum-type intrinsic pyramidal cell. For detailed descriptions see text.

cells were often identifiable in vitro, in fixed and cleared sections (Fig. 2C) the presence of 2 labels could be established with certainty.

Reliably distinguishing between layer 6 projection neurons required that retrograde labeling with microspheres correctly identified the appropriate neurons of origin. Histological inspection of injection sites confirmed that in all cases of successful retrograde transport, the injection was in the appropriate nucleus. Injections of the LGN encompassed the entire thickness of the nucleus and retrogradely labeled medium-sized neurons confined to, and distributed throughout the entire thickness of, layer 6 (Fig. $3 A, B$ ). Approximately $50 \%$ of neurons in the layer contained the granular label, which frequently extended into the proximal portion of apical dendrites (Fig. 3C). Injections centered in the claustrum labeled a prominent band, $2-3$ cell bodies thick, in the middle of layer 6 , and accounted for less than $5 \%$ of the cells in the layer. A few cells were also labeled in the superficial layers. Injections in the fiber tracts surrounding the claustrum (3 cats), and not the claustrum itself, never resulted in retrograde cortical labeling. The labeling patterns from both injection sites agree with those described using HRP (Gilbert and Kelly, 1975), and tritiated aspartate (Baughman and Gilbert, 1981; LeVay and Sherk, 1981a).

The basal dendrites, apical dendrites, and intrinsic axons of 50 LGN projecting neurons (from 4 cats) were compared with those of 30 claustrum projecting cells (from 5 cats). This analysis revealed 2 sorts of conspicuous anatomical differences: (1) Within individual layers, the 2 types had different arrangements and amounts of dendrites and axons, and (2) each cell type also had axons or dendrites in layers unoccupied by the other type. The members of each group, however, had a remarkably consistent morphology. The characteristics of each type, and their differences, are summarized in Figure 4. As shown graphically, and as described in the following sections, each projection arises from neuronal phenotypes whose characteristics can be rigorously defined and readily distinguished from those of neurons projecting to the other target. Figure 4 and the final section of the Results also present the characteristics of a third major, and previously unsuspected population of layer 6 cells: pyramidal cells that lack an efferent axon. These cells were obtained in random penetrations of slices, especially during early experiments in which the bent electrodes were not used.

\section{Morphology of neurons projecting to the visual claustrum} and LGN

\section{Claustrum projecting cells: general morphological} characteristics

Figure $4 A$ summarizes the characteristic features of the axons and dendrites of these cells; Figure 5 shows several examples of Lucifer yellow-filled claustrum projecting neurons. As a group, the claustrum projecting neurons exhibited remarkably similar laminar patterns of dendritic and axonal arborizations. Typically, these medium-sized pyramidal cells had sparse basal dendritic fields, and a single apical dendrite that reached layer 1's lower boundary. The basal dendrites, although few in number, often had extensive horizontal spread within layer 6 . The apical dendrite's few short side branches were restricted to layers 6 and 5 and absent from layer 4 . All cells had an identical laminar pattern of axon collaterals: 3 or 4 thin processes emanated from the main efferent axon and coursed horizontally within layer 6 for up to $1 \mathrm{~mm}$, occasionally giving rise to small vertical branches that terminated in lower layer 5 . These characteristics, illustrated in a camera lucida drawing of a typical claustrum projecting cell in Figure 6, are considered in greater detail below.

Somata and basal dendrites. The shapes of cell bodies varied from pyramidal to oval to almost fusiform. The injected cells are representative of at least the different size categories of claustrum projecting cells, since the average size of retrogradely labeled cells $\left(155 \mu \mathrm{m}^{2} \pm 34.7 \mathrm{SEM}, n=100\right)$ was similar to double-labeled cells (149 $\mu \mathrm{m}^{2} \pm 39.4$ SEM, $\left.n=24\right)$ (Fig. 7). Claustrum projecting cells had a very distinctive basal dendritic field structure, formed by 3-5 primary dendrites. Invariably at least one was significantly thicker, and often much longer, than the others; this branch frequently gave the soma a fusiform shape (see Figs. 6, 8, and 9A). Other dendritic branches were thinner and usually less than $150 \mu \mathrm{m}$ long. The thick processes, in contrast, extended for up to $1 \mathrm{~mm}$ horizontally in layer 6 (e.g., Fig. $9 A$ ) and branched extensively, often resulting in a highly asymmetric basal dendritic field. Figure $10 \mathrm{~A}$ shows an extreme example of this: Two asymmetric basal dendrites run horizontally 

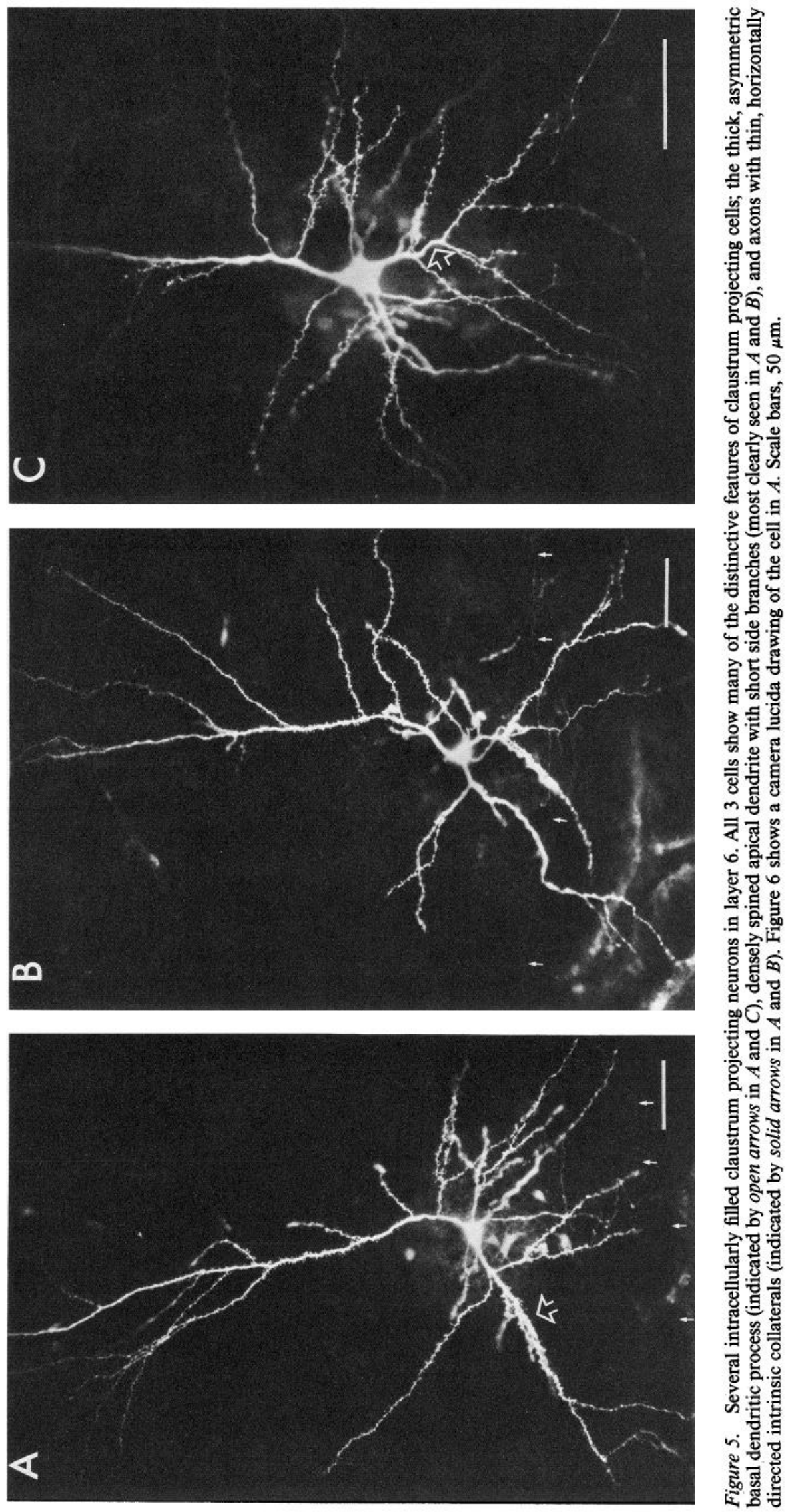


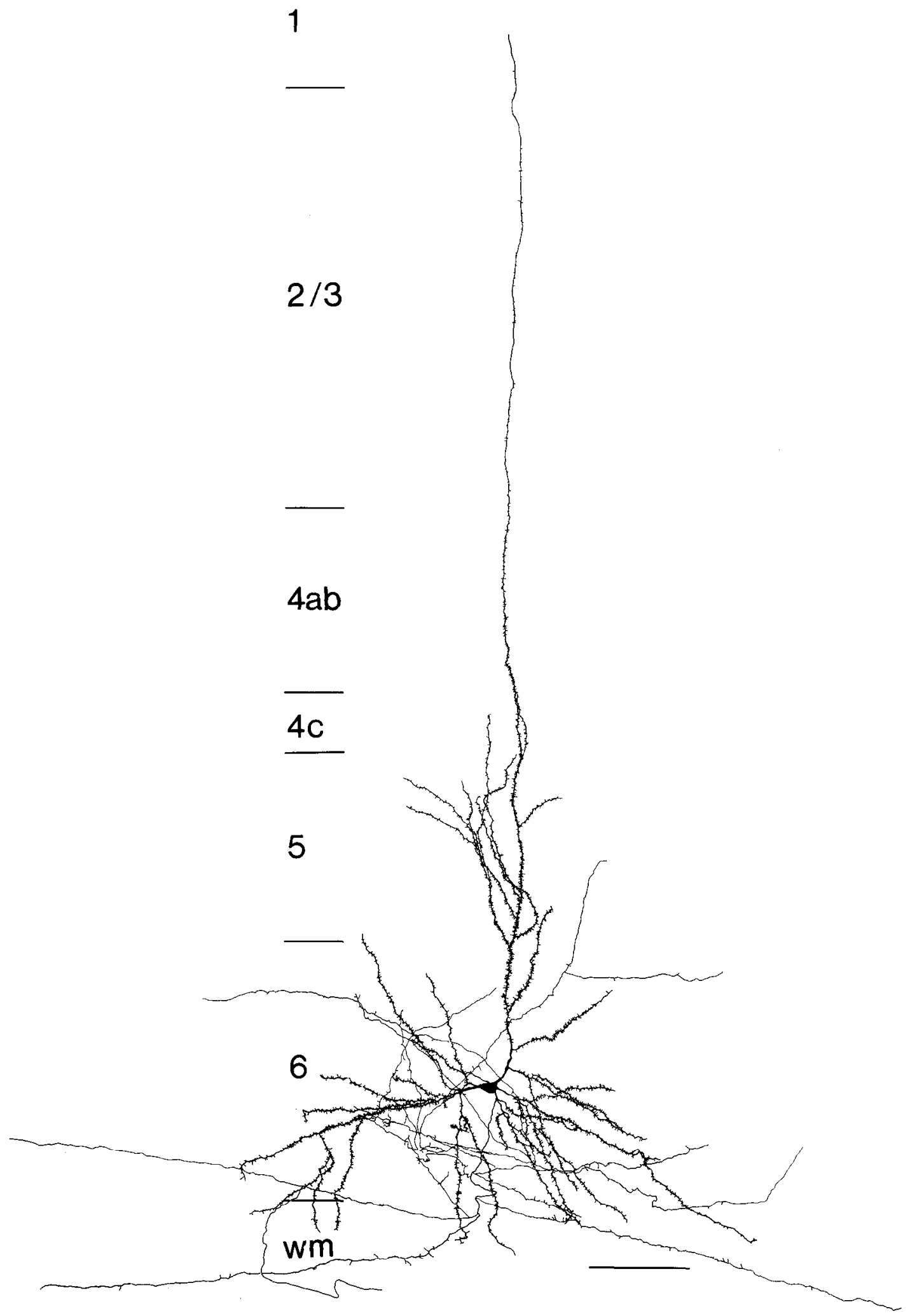

Figure 6. Camera lucida drawing of the cell shown in Figure $5 A$. In addition to the features described in that figure legend, this drawing shows the thin apical dendrite reaching layer 1 , the short dendritic branches originating from layer 5 , and the fine vertical axonal collaterals described in the text. Scale bar, $100 \mu \mathrm{m}$.

in opposite directions, forming a dendritic field almost $1 \mathrm{~mm}$ in diameter. Although all cells had a thick dendrite, sometimes (e.g., Fig. 9B) it was shorter, resulting in a more symmetric dendritic arbor. The shape of the basal dendritic arbor did not seem greatly influenced by the proximity of the white matter, and dendrites frequently extended for up to $100 \mu \mathrm{m}$ into it (e.g., Figs. 6, 8)

Apical dendrites. The single long, thin apical dendrite of most 

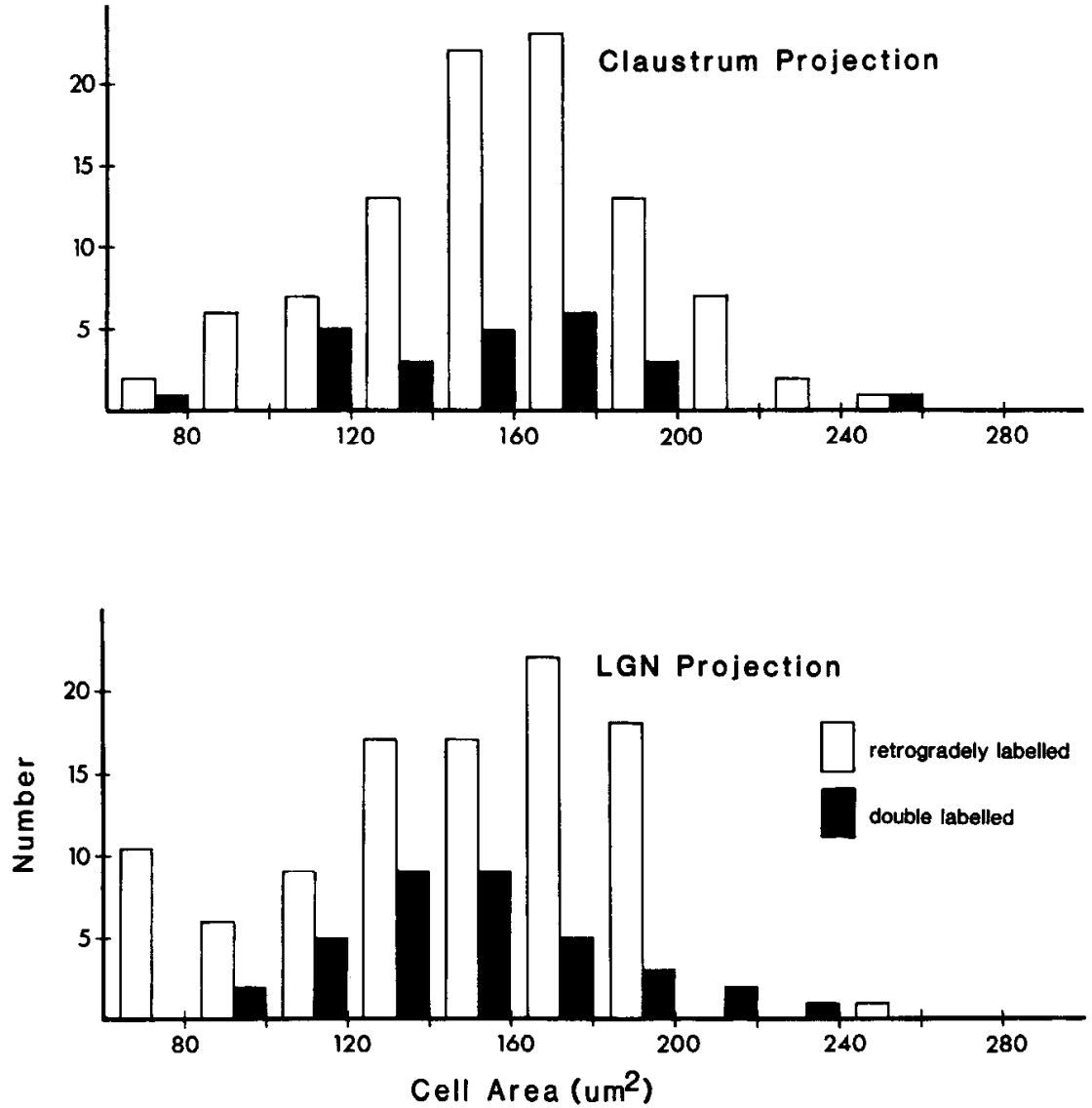

Figure 7. Size distributions of retrogradely labeled (open bars) and doublelabeled (solid bars) neurons after claustrum (top) and LGN (bottom) injections. The somatal areas are not significantly different. cells reached lower layer 1 (Figs. 6, 9) but in a few cells terminated in layer 4 (Fig. 8). In both cases, the apical dendrite branched specifically within layers 6 and 5 . These short $(200$ $\mu \mathrm{m})$, horizontally restricted processes neither originated within nor passed into layer 4 . Those originating in layer 5 coursed steeply upwards and terminated at the $5 / 4$ border, branching either once or not at all after leaving the apical dendrite. The cells in Figures 6 and 10 illustrate these features well. Generally the horizontal spread of the apical dendritic arborization was considerably narrower than that of the basal dendrites. Occasionally cells had 1 process in layer 5 with roughly twice the horizontal extent of the main apical dendritic arbor (Fig. 9). These horizontal processes gave the impression of skipping over an area of cortex about $200 \mu \mathrm{m}$ wide in order to arborize in some specific, more distant area.

The apical dendrite was densely covered with classic mushroom-shaped simple spines with narrow stalks topped by small spheres (Fig. 11A). Spine density was highest in the upper portion of layer 6 and the lower portion of layer 5 (Fig. 12) and remained high throughout layer 5 but fell dramatically in the upper layers.

Axon collaterals. The structure of the intrinsic axonal arbor provided the most consistent feature of claustrum projecting cells, and differed completely from the pattern of LGN projecting cells, as illustrated in Figure 4 and discussed further below. The main efferent axon of claustrum projecting cells, approximately $0.7 \mu \mathrm{m}$ in diameter, cmitted $3-5$ fine $(0.2 \mu \mathrm{m}$ diameter), horizontally directed collaterals while still within layer 6 . These collaterals continued in layer 6 for at least $500 \mu \mathrm{m}$ and frequently up to $1 \mathrm{~mm}$ (Figs. 6, 9B). Along this course arose various specializations, such as swellings (about $0.5 \mu \mathrm{m}$ diam- eter) and spinelike appendages, which probably represent sites of en passant synapses (LeVay, 1973; McGuire et al., 1984). Periodically, the horizontal processes emitted shorter vertically directed collaterals of the same or finer diameter, which terminated in lower layer 5 (Figs. 8, 9B). These collaterals exhibited many of the spinelike appendages seen on horizontal processes. Cells whose apical dendrite terminated in layer 4 (Fig. 8) had the most extensive horizontal and vertical collaterals, some of which appeared to be clustered (Gilbert and Wiesel, 1983).

Short collaterals occasionally originated from the main axon after it had entered the white matter. These collaterals lacked the marked horizontal orientation of collaterals originating in the gray matter and terminated either in the white matter or at the lower margin of layer 6 . The main axon itself frequently exhibited spinelike appendages in this zone (Figs. 6, 8, 10).

\section{LGN projecting cells: general morphological characteristics}

As a group, the morphology of geniculate projecting cells varied considerably more than the claustrum projecting cells. Differences in axons and dendrites distinguished 2 types, illustrated schematically in Figure $4, B$ and $C$, both with similar cell body sizes. Most (>80\%), termed here type I cells (Fig. $4 B$ ), were medium to large pyramidal cells with a dense, symmetric basal dendritic arbor and a highly branched apical dendrite that reached lower layer 3. Axon collaterals were rare in layer 6 , but numerous recurrent collaterals ran to and arborized within layer 4. About $20 \%$ of geniculate projecting cells, termed type II cells (Fig. $4 \mathrm{C}$ ), had smaller, sparser basal dendrites, and apical dendrites ending at or below layer $4 \mathrm{C}$. The axon collaterals, thin and sparse, arborized locally only within layers 6 and 5 .

Somata and basal dendrites: type I cells. Figure 13 shows 


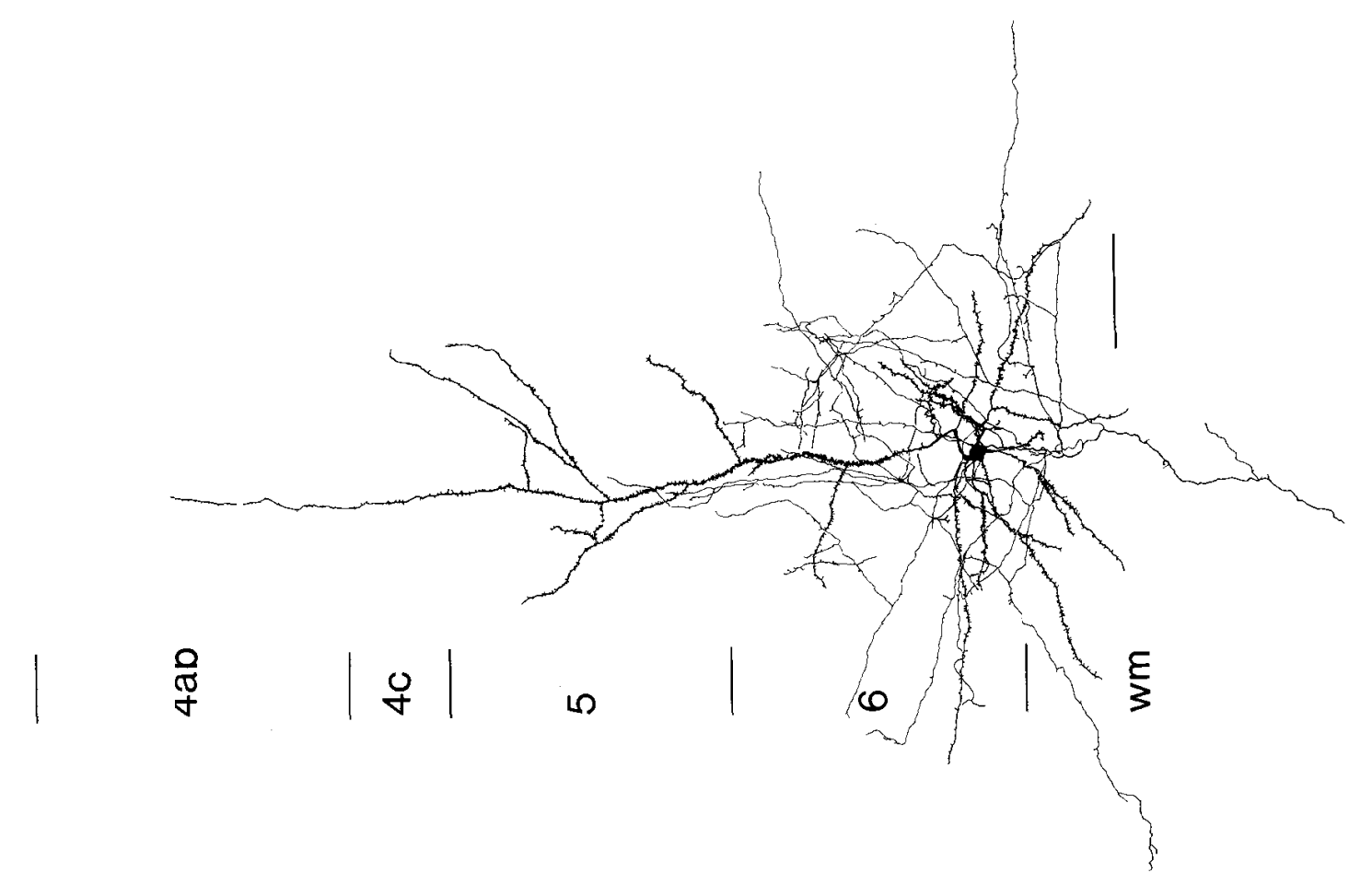

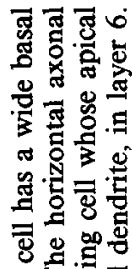

昰焉

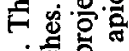

远

둥

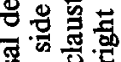

蛋要要

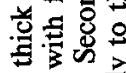

的事

苟它

要要

8 .

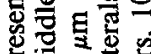

․․ 8 의

g

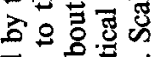

$m$

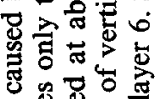
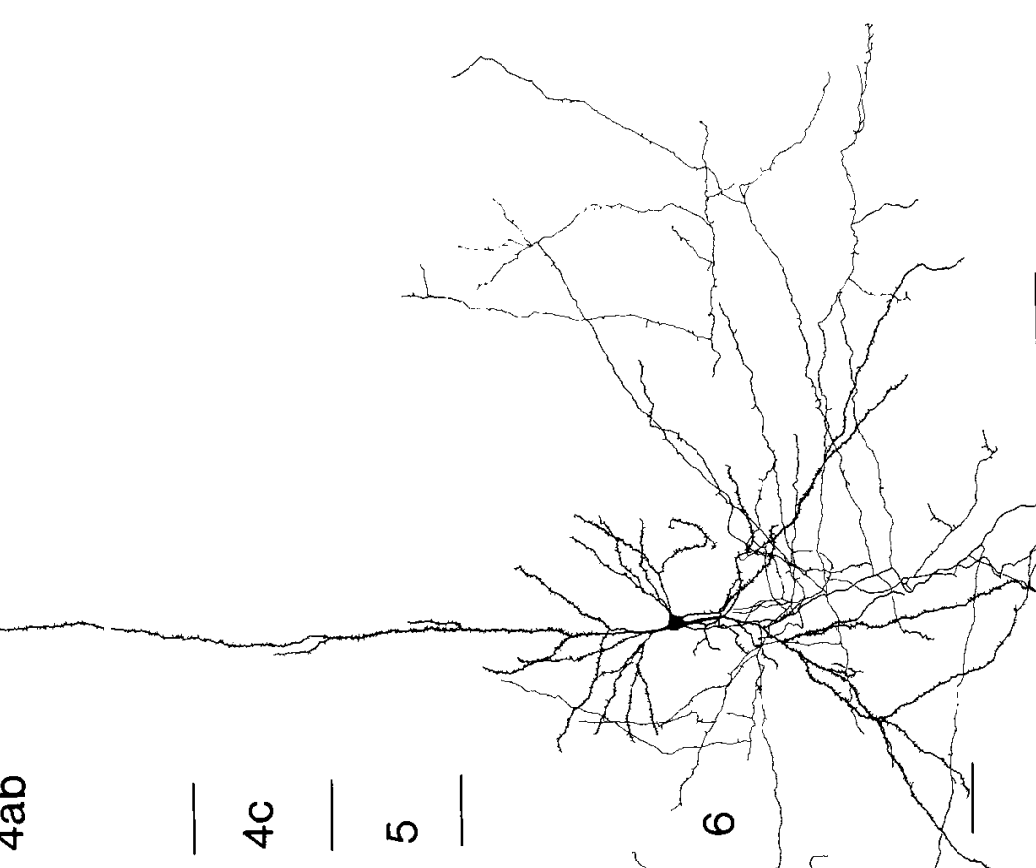

on $\bar{d}$ c

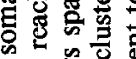

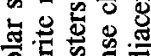

\&

의

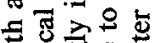

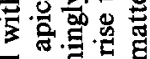

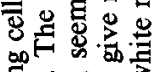

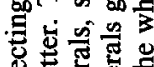

更

记

西

善里总

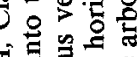

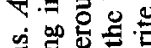

.

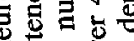

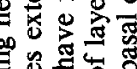

$\left|\begin{array}{l|l|l|}\frac{0}{7} & 0\end{array}\right|$

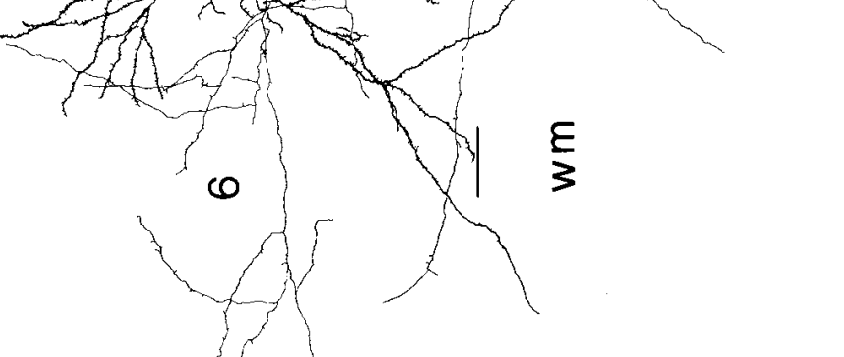

$\varangle$

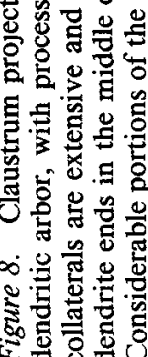



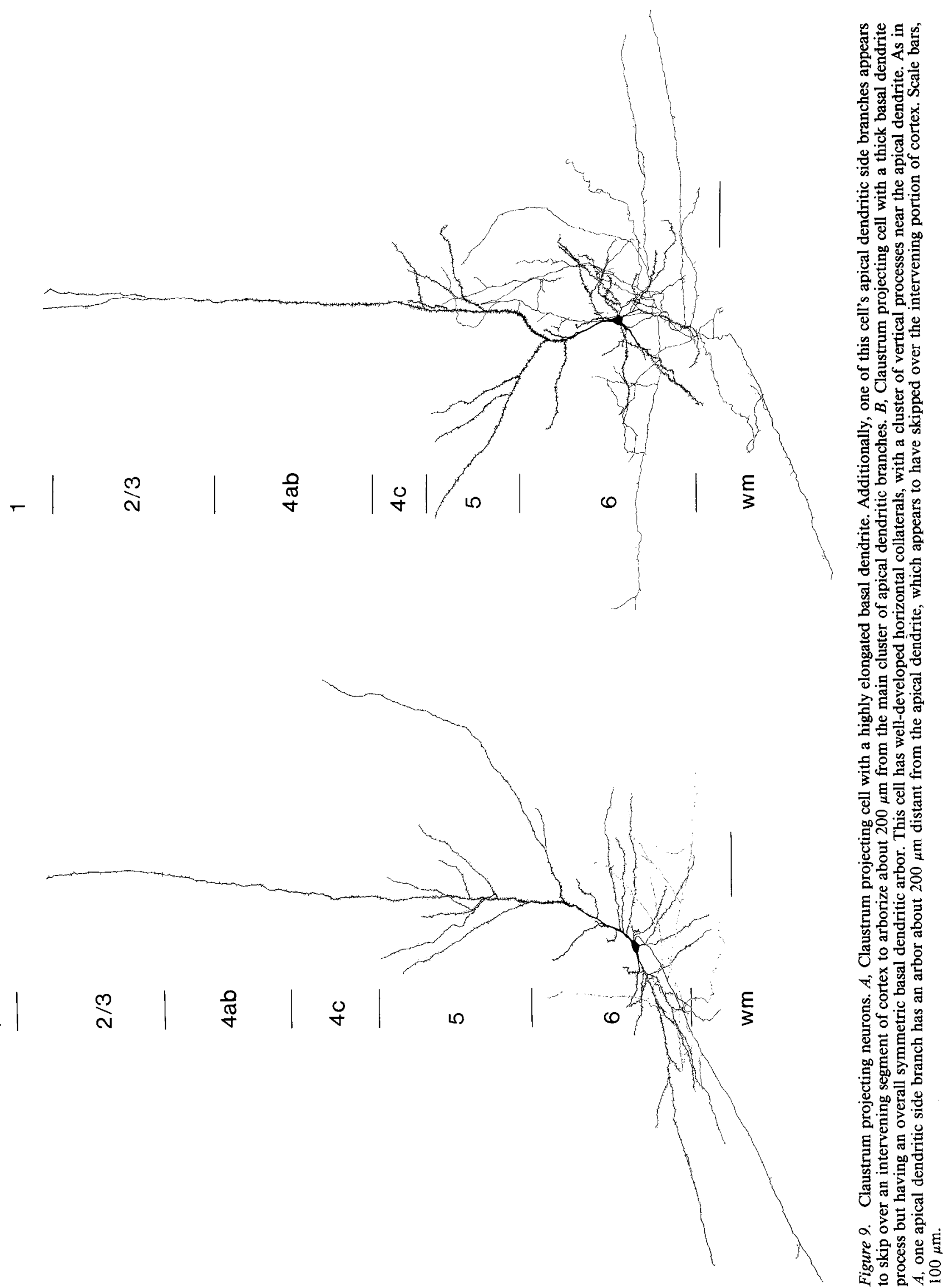


\section{A}

1

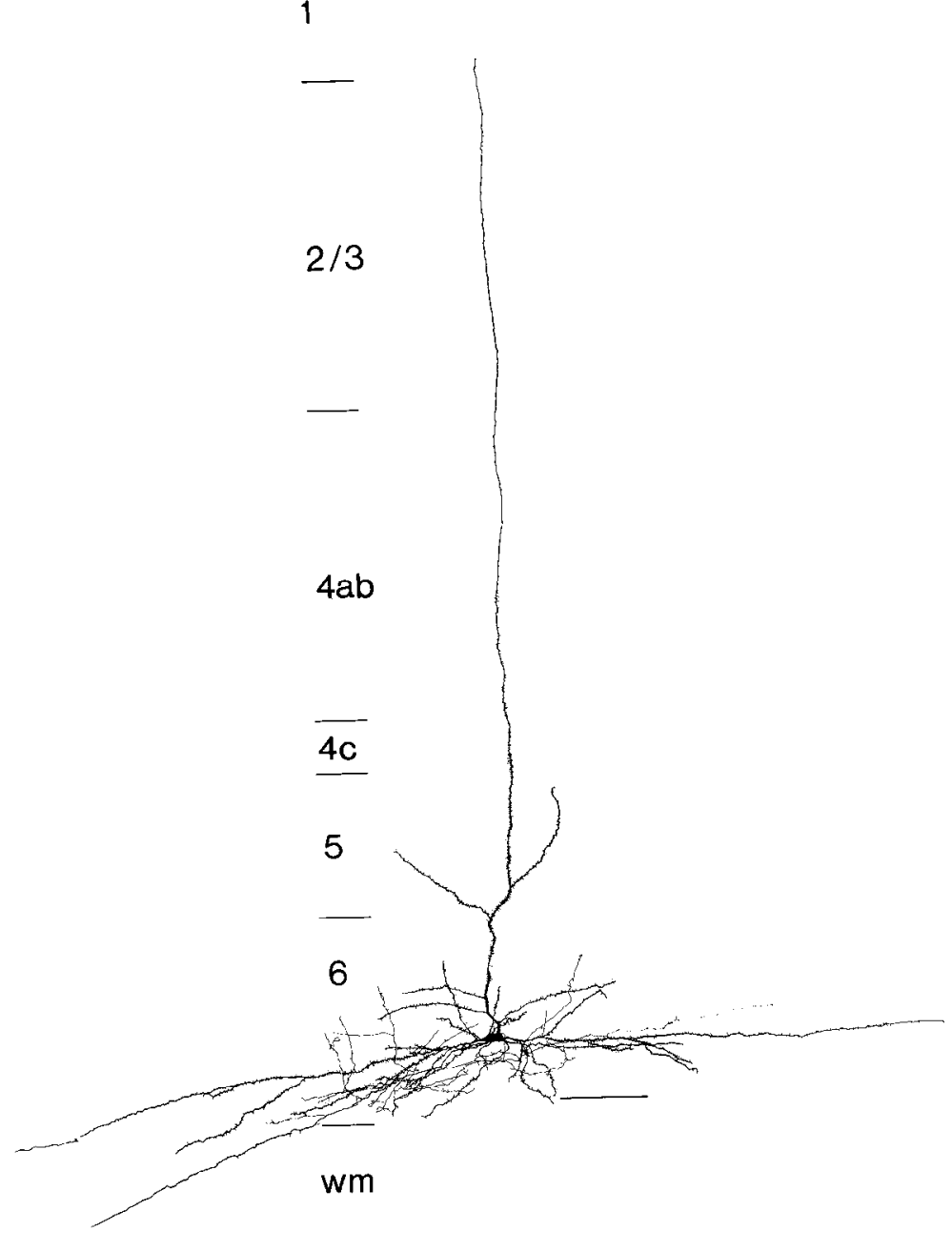

1

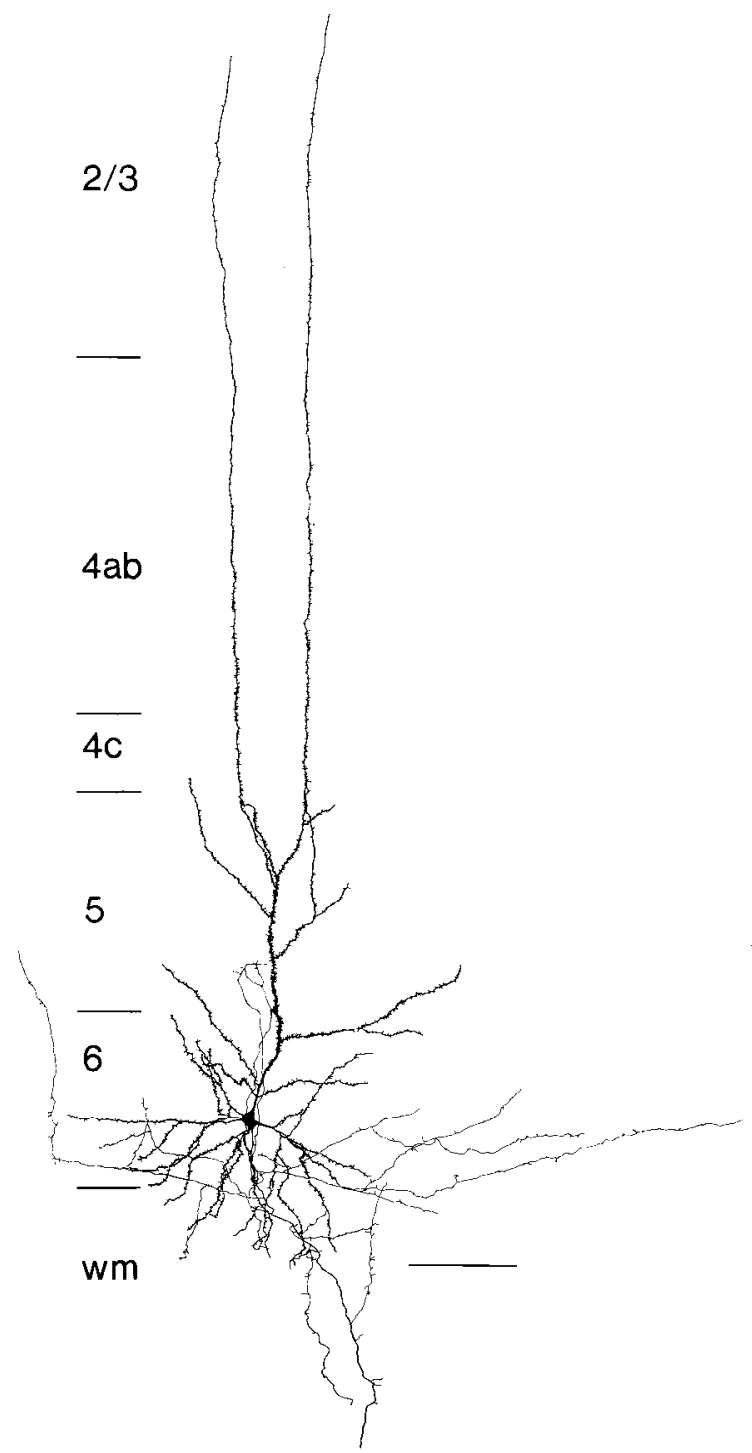

Figure 10. Claustrum projecting neurons. A, Claustrum projecting cell with an extreme example of the basal dendritic asymmetry and difference in horizontal extent of basal and apical dendrites. Two basal dendrites run in opposite directions, forming an arbor almost $1 \mathrm{~mm}$ in diameter. In contrast, the spread of the apical dendritic side branches is about $200 \mu \mathrm{m}$. $B$, An unusual claustrum projecting neuron with 2 thin apical dendrites. In other respects the cell shows the standard axonal and dendritic features of claustrum projecting cells. Scale bars, $100 \mu \mathrm{m}$.

several examples of these cells. Some type I cells had a distinctive small, oval soma, approximately $12 \mu \mathrm{m}$ along the long axis, which ran parallel to the gray/white matter border. The cell body area of less than $120 \mu \mathrm{m}^{2}$ placed these cells on the small side of the size range of geniculate projecting neurons (overall, retrogradely labeled cells averaged $143 \mu \mathrm{m}^{2} \pm 41.5 \mathrm{SEM}, n=$ 100 ; Fig. 7). Other cells had larger, more standard pyramidally shaped cell bodies. The $6-8$ basal dendritic arms, of similar thickness and length, branched profusely close to the cell body, yielding a dense, compact, and symmetric basal dendritic arbor with a radius of approximately $150 \mu \mathrm{m}$ (Figs. 14, 15). Cells close to the white matter often oriented their dendrites parallel to the border rather than penetrating it. Unlike claustrum projecting cells, geniculate projecting cells' basal dendrites generally avoided the white matter.

Apical dendrites: type I cells. The apical dendrites of type I cells always ended in or below layer 3 . Along their course, these dendrites produced numerous branches in layers 6,5 and 4 . The horizontal extent of the apical dendritic field was always greater than that of the basal dendrites, ranging from 1.5 to 3 times as extensive. In some cells, long horizontal branches originated in layer 5 and exited from the apical dendrite at almost right angles. These side branches coursed through layer 5, occasionally producing an apical dendritic arbor more than 700 $\mu \mathrm{m}$ wide (Fig. 15). Other branches, particularly those in layer 4 , left the apical dendrite at considerably steeper angles and did 

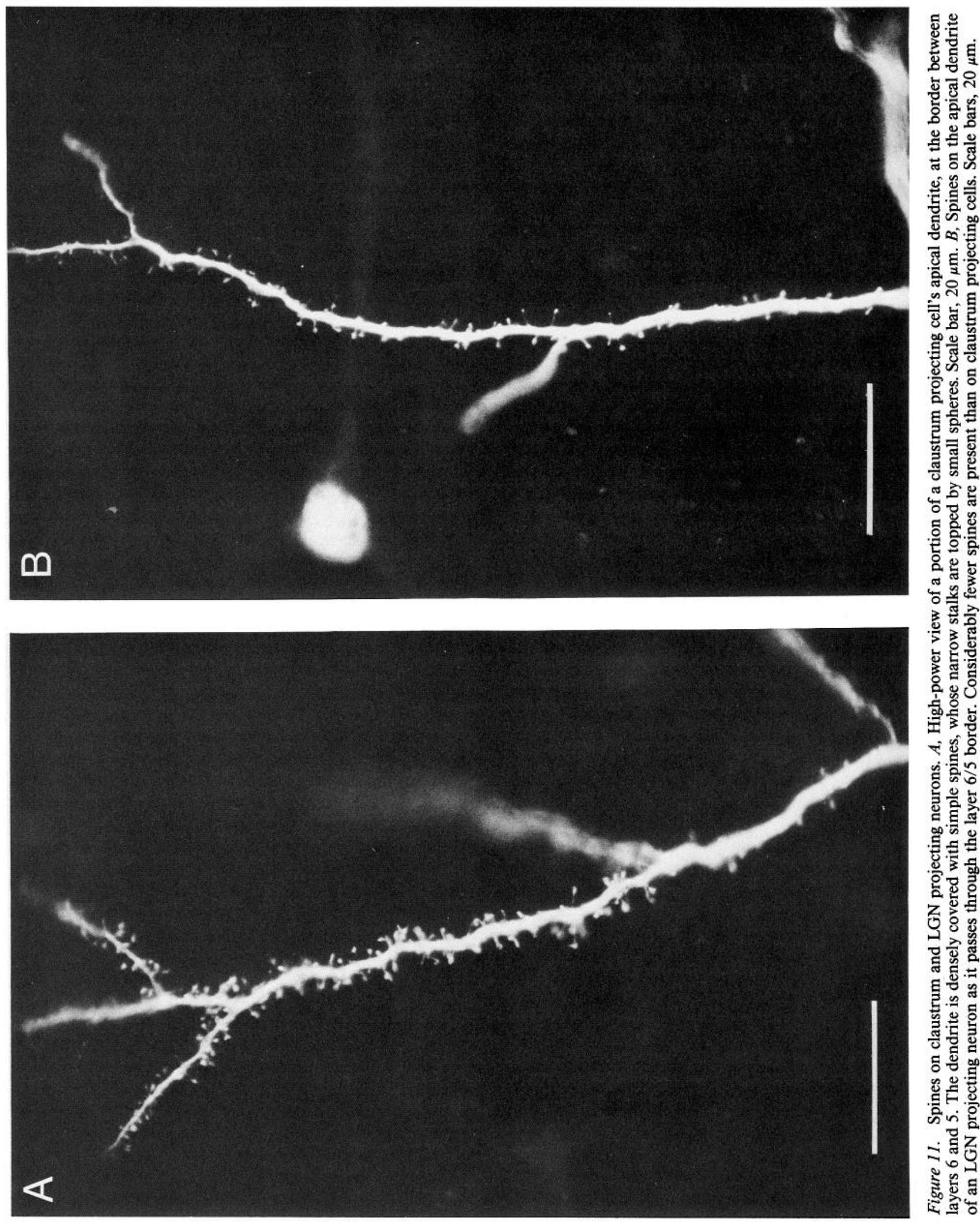
政 
Claustrum proj. cells
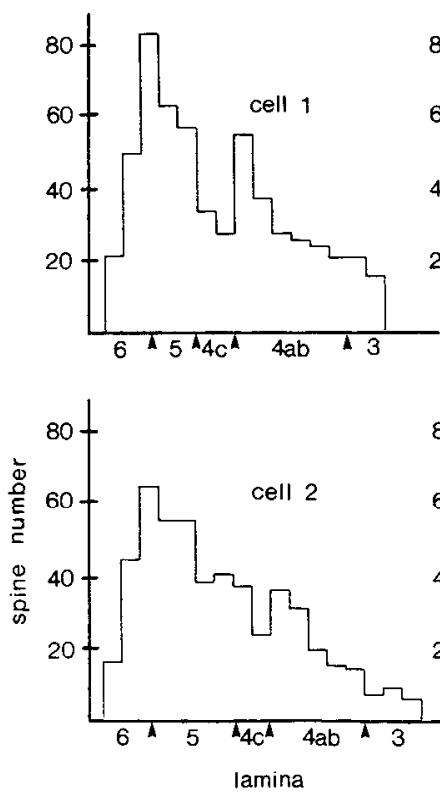

Figure 12. Numbers of spines along the apical dendrite of representative claustrum and LGN projecting neurons. Counts were made along $40-\mu \mathrm{m}$-long segments in individual neurons qualitatively judged to be near the mean of each group. Both projection classes showed a prominent peak of spine density at the layer $6 / 5$ border; some claustrum projecting cells had a smaller secondary peak at the $4 \mathrm{C} / 4 \mathrm{AB}$ border.

not show such considerable horizontal extent. The layer 5 side branches of other cells formed a somewhat narrower $(350 \mu \mathrm{m})$ apical dendritic field. Both types of dendritic branches of type I cells branched either once or not at all after leaving the apical dendrite.

The apical dendrites were lightly to moderately spined. Spine concentration peaked near the layer $5 / 6$ border (Fig. 12B) and remained high in layer 5 but dropped off considerably in layer 4 .

Axon collaterals: type I cells. As with claustrum projecting cells, the laminar pattern of the intrinsic axonal arbor was the most consistent and obvious feature of geniculate projecting cells, as well as the most dramatic difference between the 2 projection classes (compare Fig. $4, A$ and $B$ ). Type I cells had a prominent efferent axon (0.5-1.0 $\mu \mathrm{m}$ diameter) that, before entering the white matter, emitted 3-5 vertically directed axonal collaterals. Only slightly less thick than the parent axon, these collaterals ascended, branching occasionally, and reached layer 4. Here, they began branching extensively, exhibiting prominent spinelike appendages at frequent intervals along their length (Figs. 14, 15). In contrast to these well-developed recurrent collaterals, collaterals within layer 6 were rare, frequently consisting of no more than an occasional process less than $50 \mu \mathrm{m}$ long (Figs. 14, 15), although in 1 cell (out of 50), several 150 $\mu \mathrm{m}$ processes were observed.

Cells with the most widespread apical dendrites also had the most widespread and thickest $(0.7-0.9 \mu \mathrm{m}$ diameter) recurrent collaterals. These collaterals extended laterally up to $1 \mathrm{~mm}$, measured at the layer 5 and $4 \mathrm{C}$ boundary, and even farther within layer 4 . Cells with more horizontally restricted apical dendrites had considerably thinner $(0.3-0.5 \mu \mathrm{m}$ diameter) and more horizontally restricted ascending collaterals, which generally remained within the confines of the cells' apical dendrites. In their course through layer 5 , they had occasional spinelike appendages or short branches. In contrast, the thicker, widespread collaterals only rarely had such processes.

Many type I cells exhibited short collaterals and spinelike appendages in the zone of white matter approximately $100 \mu \mathrm{m}$ below the border of layer 6 and white matter. The postsynaptic targets of such processes are unclear. Since most geniculate projecting cells' dendrites generally do not cross into the white matter, these short collaterals probably do not extensively contact the basal dendrites of other geniculate projecting neurons.

Somata and basal dendrites: type II cells. These cells had a range of soma sizes and shapes similar to type I cells. Occasionally a very small cell was filled (Fig. $16 A$ ), but many were of standard pyramidal shape and size (Fig. 16B). As in type I cells, the basal dendritic arbor consisted of 6-8 thin arms, of roughly equal length, arranged radially around the soma, forming an arbor about $150 \mu \mathrm{m}$ in diameter.

Apical dendrites: type II cells. Type II cells had thin, poorly developed apical dendrites. Some reached the lower part of layer 4 , but most terminated at the $5 / 4$ border. The dendritic spines were concentrated in layer 6 and decreased markedly within layer 5 . Side branches originated only in layer 6 , and extended horizontally less than the cell's basal dendrites (Fig. 16).

Axon collaterals: type II cells. Compared to type I cells, type II cells had considerably restricted intrinsic axon collaterals. None of the thin $(0.2-0.3 \mu \mathrm{m}$ diameter) ascending collaterals reached higher than layer 5 . Within layer 6 most collaterals stayed within the boundaries of the basal dendrites. Figure $16 B$ shows a cell with one of the most extensive collateral systems encountered among type II cells.

Axon diameters of $L G N$ projecting neurons. Unlike the axons of claustrum projecting cells, geniculate projecting cells had at least a 3-fold difference between the smallest and largest diameter axons, ranging from less than 0.3 to greater than $1 \mu \mathrm{m}$ in diameter. Diameters of the efferent and recurrent axon collaterals were highly correlated $\left(r^{2}=0.88, p<0.001\right)$. This variability did not result simply from larger cells having large axons, since soma area and efferent axon size were uncorrelated $\left(r^{2}=0.18, p>0.2\right)$. The limited resolving power of the light microscope (about $0.3 \mu \mathrm{m}$ ) prevents distinguishing whether these groupings reflect distinct classes or the distribution of a parameter along a continuum.

\section{Summary and quantitative comparison of claustrum and geniculate projecting cells}

The principal features of the cells described thus far are diagrammed in Fig. $4, A, B, C$. Even casual inspection reveals that the basal dendrites, apical dendrites, and axonal collaterals of these projection classes are markedly different. In this section, some of those differences are quantified in order to give a firm basis to the qualitative impressions. Since type I cells are by far the more common type of LGN projecting cell, these are used in the analyses that follow.

Somata and basal dendrites. Claustrum and LGN projecting cells have similar size cell bodies (Fig. 7), although the smallest geniculate projecting cells $\left(<80 \mu \mathrm{m}^{2}\right)$ were smaller than any claustrum projecting cclls. Claustrum projecting cells have about a third fewer basal dendritic arms (3-5) than lateral geniculate projecting cells (6-8), a highly significant difference (Student's $t$ test, $p<0.01$ ). The presence of 1 or 2 thick, long dendrites, a feature never observed in geniculate projecting cells, gives the claustrum projecting cells a markedly asymmetric basal dendritic field, compared to the characteristically symmetric field 

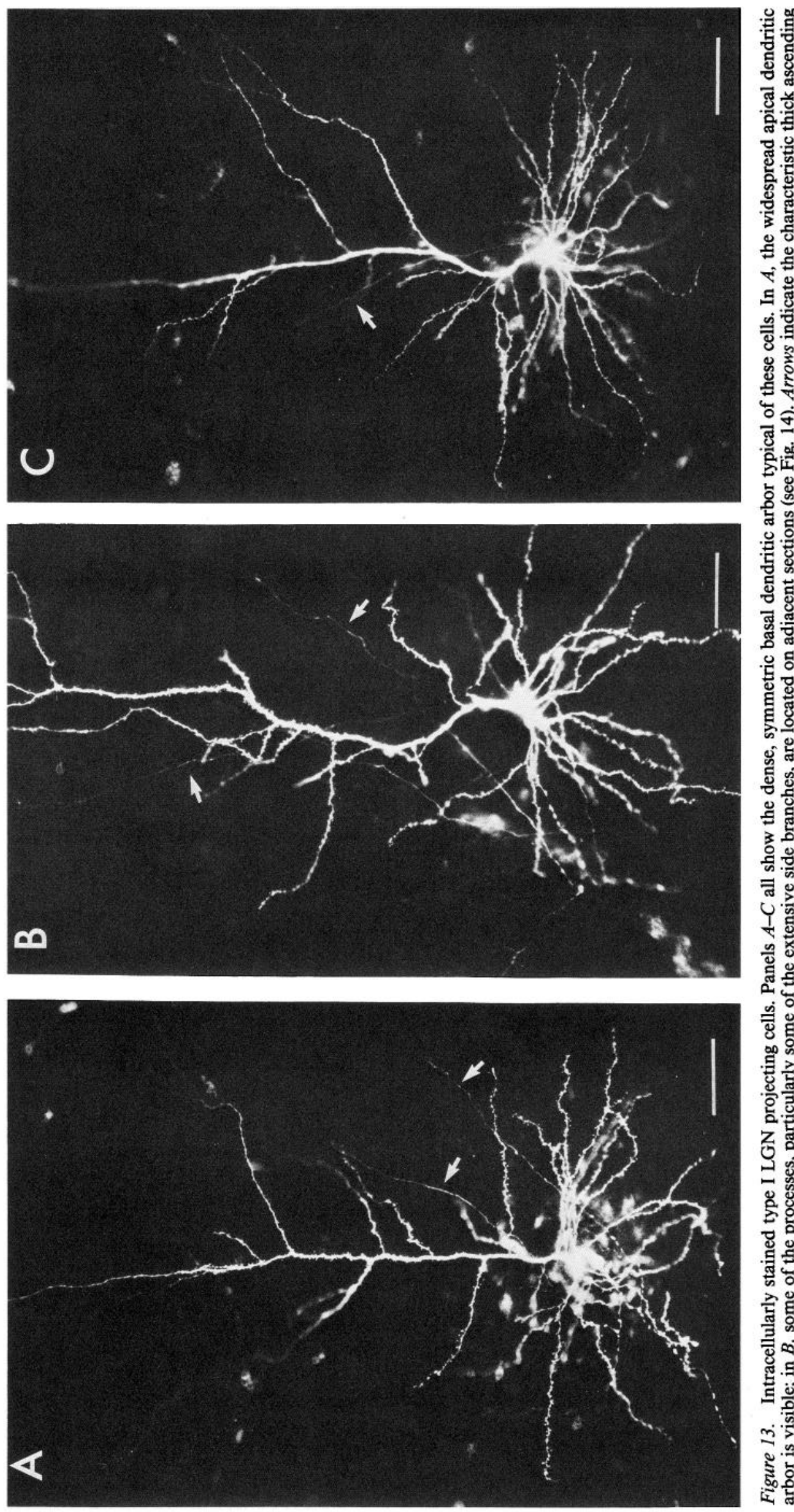

ष्ठ

요

틀

을.

$z$

ชิ

\%

is

20

해

o

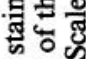

근 무

宩

击心

의

实䟢

r.

.

s. 
3

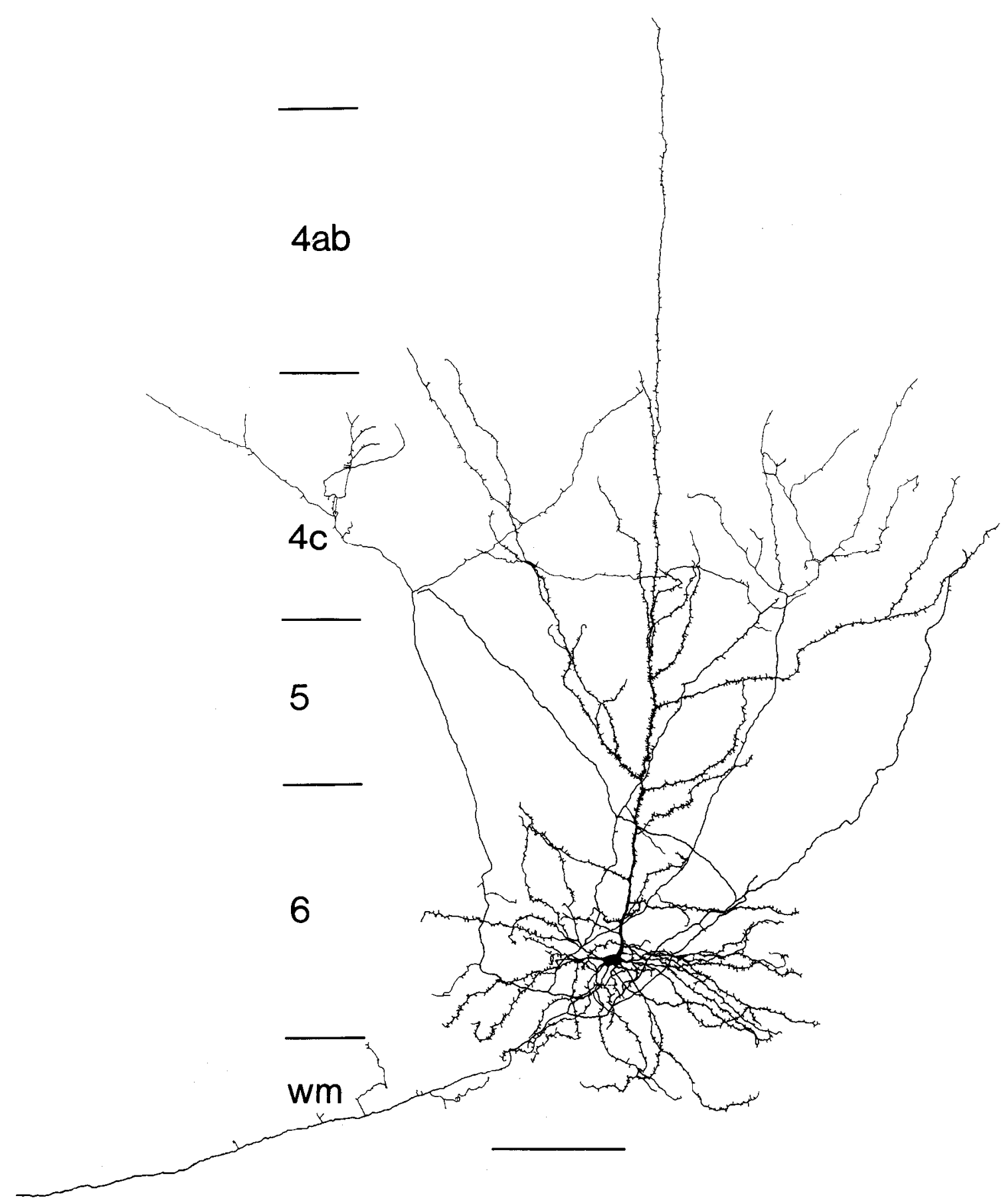

Figure 14. An example of a typical type I LGN projecting neuron. This cell has a small soma, with 7 basal dendritic arms of equal length arranged radially around it. The apical dendrite reaches only to layer 3, with long horizontal side branches in 5 and 4 . Note the extensive collateral arborization in layer 4, the thick ascending collaterals, and the complete absence of horizontal collaterals within layer 6 . A few unmyelinated collaterals originate from the axon in the white matter $(w m)$ immediately subadjacent to layer 6 .

of geniculate projecting cells. This feature gives rise to the extended "tail" in the Sholl analysis of the claustrum projecting cells' basal dendrites (Fig. 17A). However, the 2 projection classes show similar branching patterns for the initial $100 \mu \mathrm{m}$ of dendritic length (Fig. 17A). The dendrites of claustrum projecting cells do not generally respect the gray/white matter boundary, but those of geniculate projecting cells usually do.
Apical dendrites. The apical dendrite of claustrum projecting cells characteristically reaches layer 1 ; geniculate projecting cells never reach above layer 3 . However, the geniculate projecting cells have an extensive apical dendritic arbor, with branches in layers 6, 5, and 4. Figure $17 B$ shows a Sholl analysis of the apical dendritic branching patterns of geniculate and claustrum projecting cells, which demonstrates the more profuse branching 


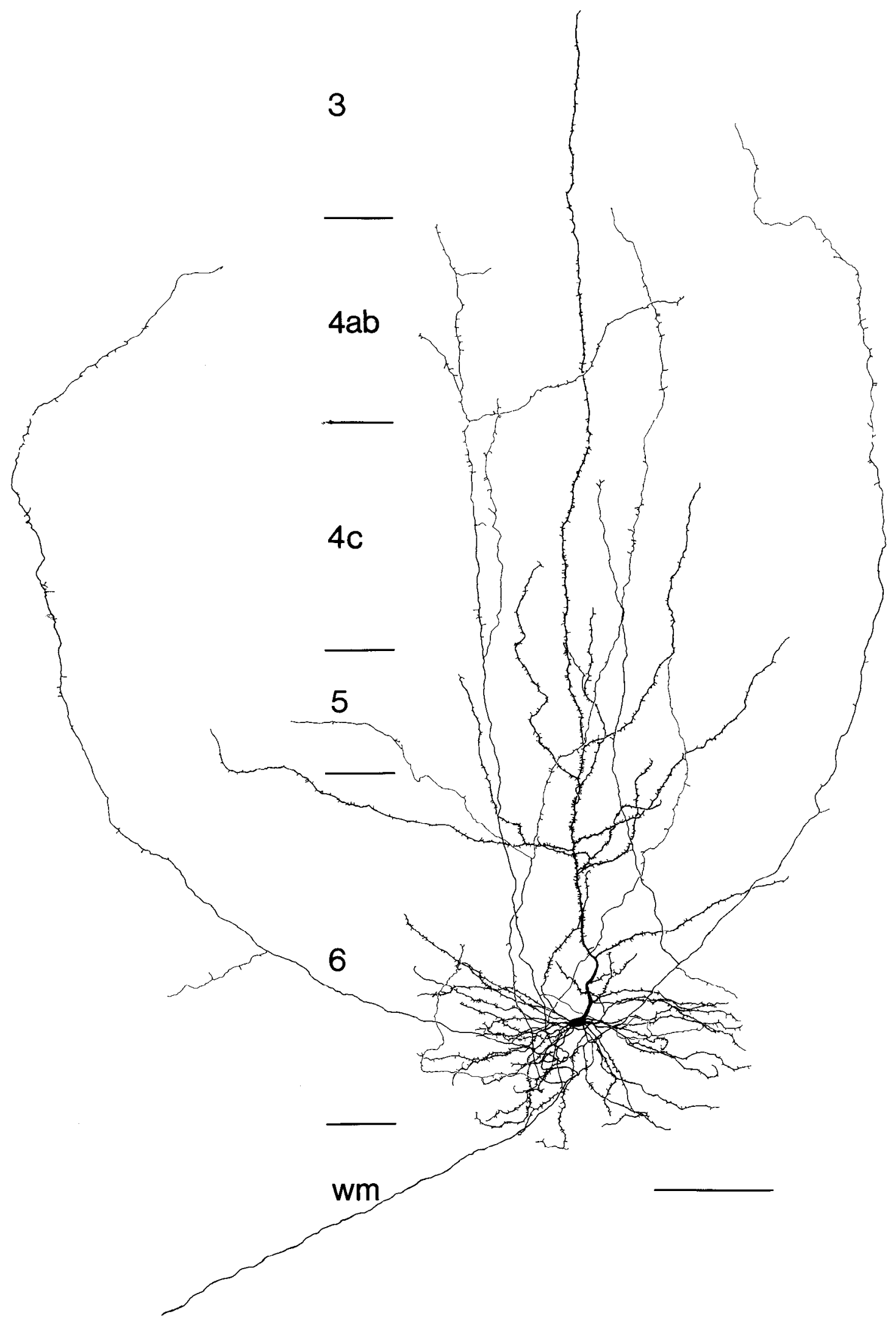

Figure 15. A second type I LGN projecting neuron, similar to that shown in Figure 14. In this neuron the apical dendritic branches in layer 5 form an arbor more than $500 \mu \mathrm{m}$ in diameter, in contrast to the considerably smaller basal dendritic arbor, which is about $300 \mu \mathrm{m}$ in diameter. The ascending collaterals, which have only a small subcollateral in layer 6 , arborize over an extensive area in layer 4 . Scale bar, $100 \mu \mathrm{m}$. 


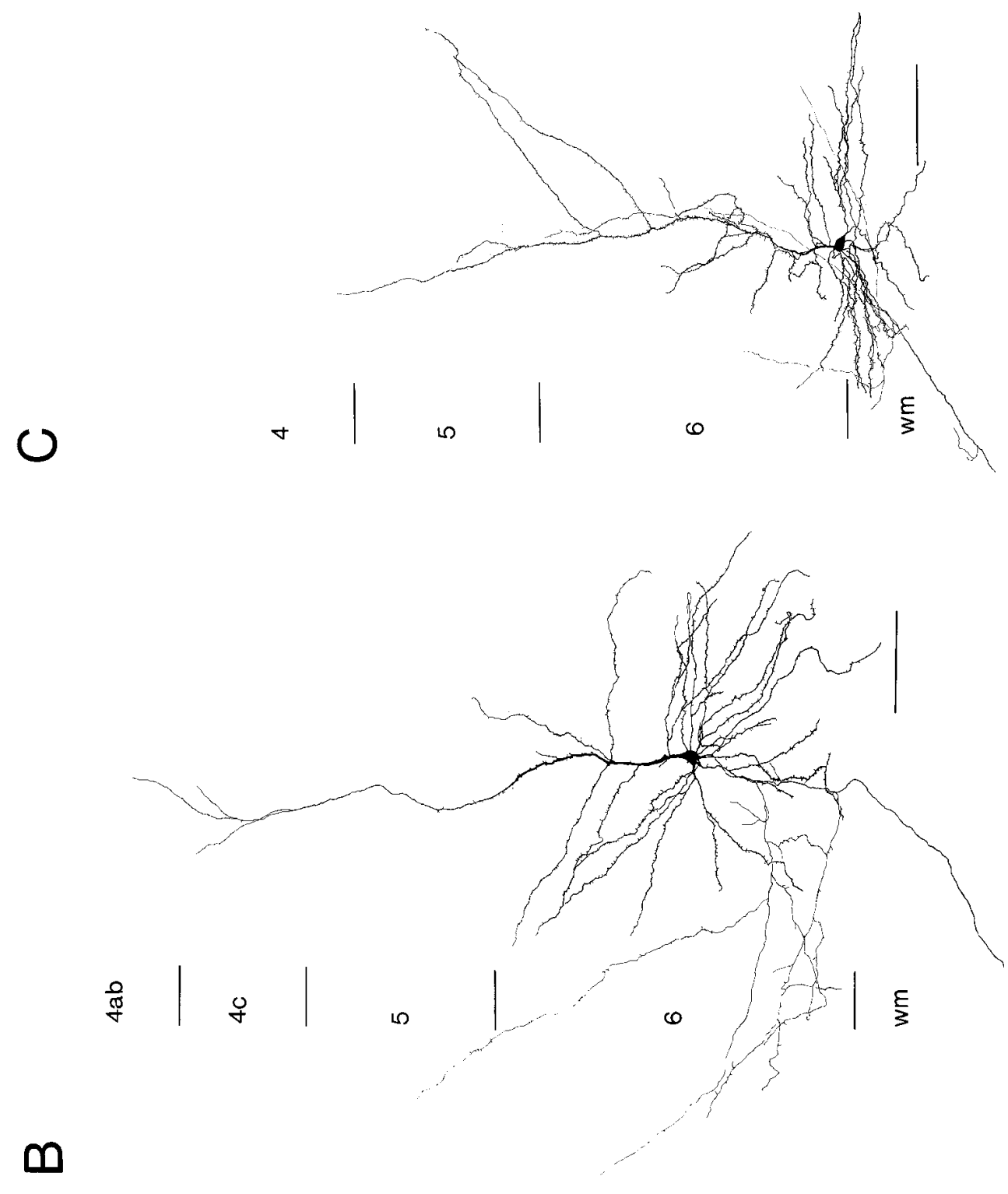

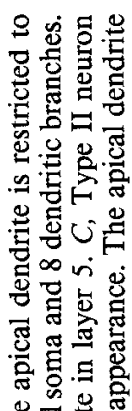

田总。

宊焉焉

落客

惫苍文

照

형명

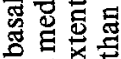

更

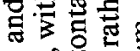

요율

을오 점ㅇ

元

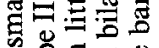

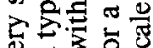
$>$ च

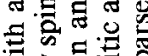

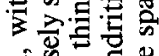

की है

की

s.

它号家

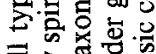

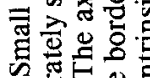

षं क्ष

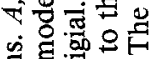

品究

政

엡

可示

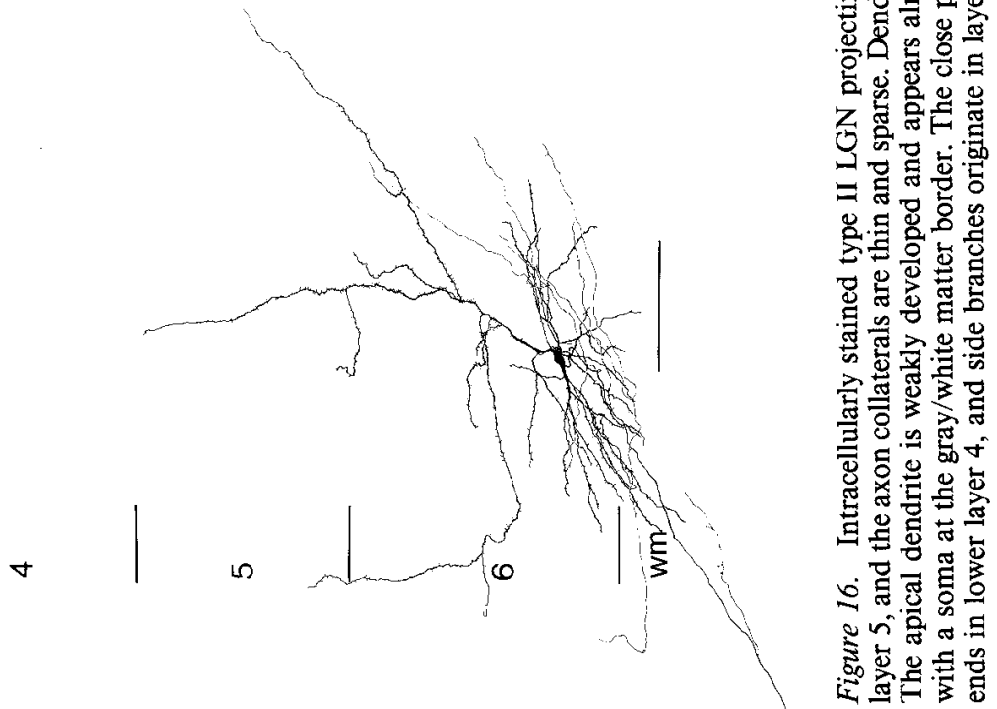




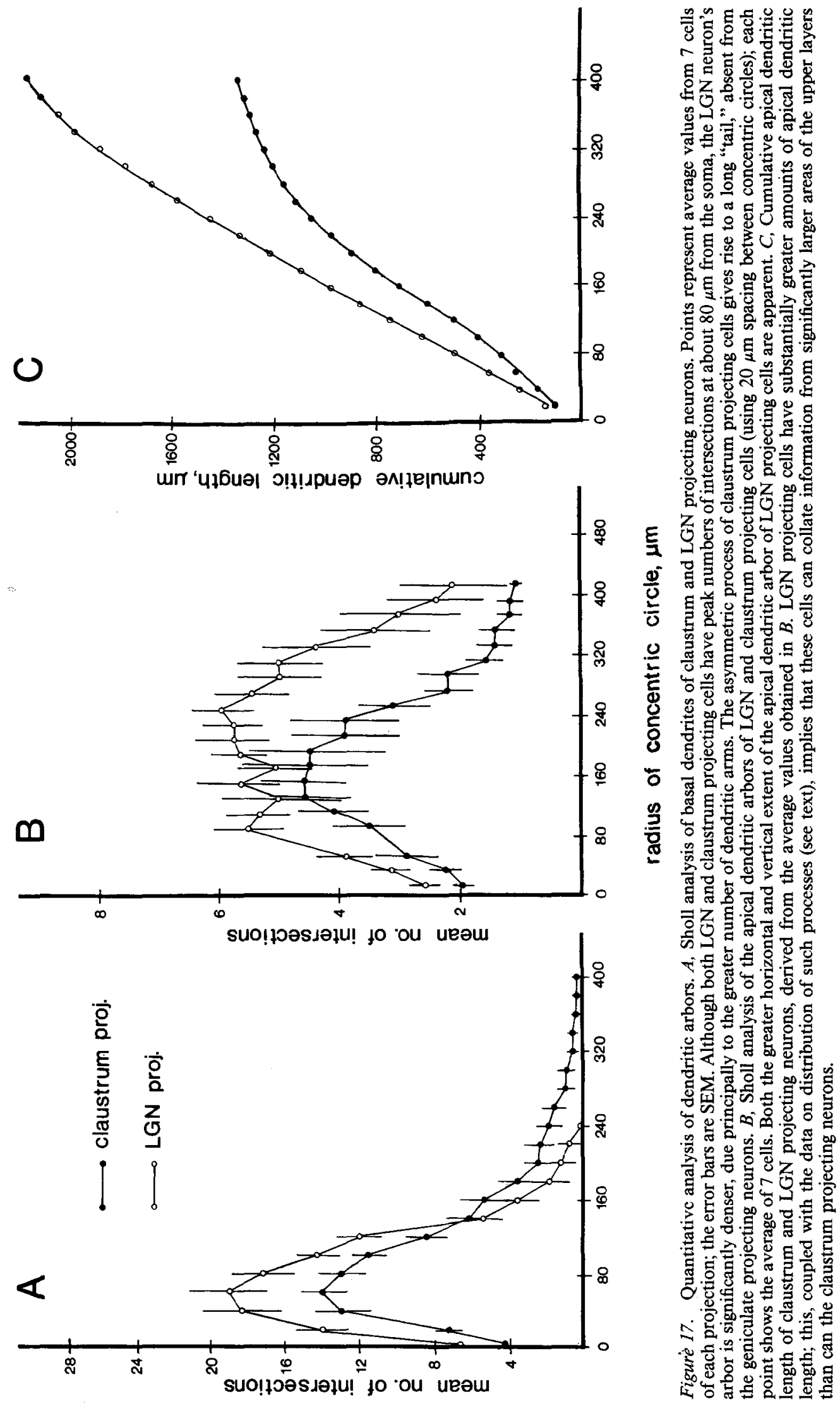


of the geniculate projecting cells' apical dendrites. The horizontal extent of these branches is often considerably greater than that of the basal dendrites. In contrast, the apical dendrite of claustrum projecting cells has only short branches in layers 6 and 5, so that the horizontal extent of the apical dendritic arbor is considerably narrower than that of the basal dendrites. In terms of total length, geniculate projecting cells have an apical dendritic arbor about $50 \%$ larger than claustrum projecting cells (Fig. 17C).

Claustrum projecting cells have roughly twice as many dendritic spines along a given section of apical dendrite as geniculate projecting neurons. Both have peak numbers of spines at the $6 / 5$ border. Geniculate projecting cells often have a second peak at the $3 / 4$ border, a feature absent from claustrum projecting neurons.

Intrinsic axonal arborizations. All claustrum projecting cells had thin, horizontally directed axon collaterals that coursed extensively within layer 6 and never rose above layer 5 . The geniculate projecting neurons, in marked contrast, had virtually no horizontal collaterals within layer 6 but possessed instead ascending collaterals that arborized extensively within layer 4 . The efferent axons of both cells had occasional collaterals or appendages within a $100-\mu \mathrm{m}$-thick zone of white matter immediately subadjacent to layer 6 .

\section{Nonprojecting pyramidal cells in layer 6}

In early experiments, random Lucifer yellow fills of cells in layer 6 suggested that approximately $20 \%$ of filled cells lacked an efferent axon, despite excellent filling in other respects. Figure $18 \mathrm{~A}$ shows an example of a cell of this type (illustrated schematically in Fig. 4D). In these cells, a thick axonal process left the soma, proceeded towards the white matter for about 100 $\mu \mathrm{m}$, and then turned lowards the pia by making an abrupt $\mathrm{U}$-turn. The axonal process of another such cell shows this behavior in more detail in Figure $18 B$. At the bottom of the $U$, the thick axon occasionally produced a short, very thin collateral that either ended within layer 6 or continued briefly within the white matter before terminating. Before the U-turn, the thick axon also sent off several collaterals only slightly thinner than the parent axon. These processes also turned towards the pia. Occasionally in layer 6 they gave rise to thin vertical collaterals that arborized within layer 5 . Although in some cases both the parent axon and its collaterals could be traced for more than 1 $\mathrm{mm}$, the final terminal arborizations either were not filled completely or, more likely, were truncated in the slicing process.

The overall pattern of the intrinsic axonal arbor strongly resembled type I geniculate projecting cells: thick, vertically oriented axons with sparse collateralization within layer 6 . In most cases the dendritic arborizations also resembled that of type I geniculate projecting neurons (compare Fig. 4, $D$ and $B$ ). The 6-8 basal dendrites, all of approximately equal thickness and length, formed a symmetric field. The apical dendrites terminated in layer 3 and had side branches in layers 6 and 5. Moderate numbers of spines covered both apical and basal dendritic processes (Fig. 19A).

A second type of intrinsic pyramidal cell, encountered much less frequently, had features of basal and apical dendrites, as well as intrinsic axonal arbors, very similar to those of claustrum projecting neurons (Figs. 4E, 19B). In these cells, 3-5 basal dendrites, with one considerably thicker than the rest, formed an asymmetric basal dendritic arbor. The thin apical dendrite reached layer 1 , branching only in layers 6 and 5 . Both apical and basal dendrites had many spines. The thin intrinsic axons of these neurons ran horizontally within layer 6 and never rose above lower layer 5. Although usually not as profuse as most claustrum projecting cells, the axon's horizontal extent seemed greater; in several cases a single process extended for over 1 $\mathrm{mm}$.

\section{Discussion}

\section{Brain slices as a neuroanatomical tool}

Despite the popularity of brain slices for physiological investigations, their use in anatomical studies has been very limited. Slices have several clear advantages over both Golgi techniques and in vivo intracellular staining. Compared to Golgi techniques, neurons intracellularly stained in slices have (1) fewer truncated processes, due to the use of thicker slices; (2) excellent filling of axons, even in adult animals; and (3) directed, nonrandom filling of specific cells in specific cortical regions. This last point is also an advantage over in vivo intracellular staining, in which it is very difficult to direct the electrode to individual, identified cells. Furthermore, the stability of intracellular impalements in slices, compared to that in vivo, allows many more neurons to be stained in each animal. The main drawback in using slices is the inevitable truncation of processes, particularly long axons. Although superior in this respect to Golgi staining, slices nevertheless cannot compare to in vivo intracellular fills in the completeness of collateral staining. This was particularly evident when the projection to layer 4 originating from LGN projecting neurons filled in vitro was compared to similar cells filled in vivo: The density of axon terminals, even in the best in vitro cases, was considerably less than that seen in the best in vivo examples. The problem of truncation is also present, to a lesser extent, in visualizing the dendritic arbor of cells. Hence, slices should not be relied upon to give rigorous quantitative information on the strength of a given intrinsic connection.

\section{Significance of morphological differences in cortex}

The diversity of cortical cell types, and pyramidal cell types in particular, is one of the basic facts of cortical organization. However, whether this diversity is meaningful in terms of cortical function is an open question. Analyses of pyramidal cell structure in terms of classical receptive field properties (via intracellular recording and staining) actually suggest that the detailed structure of cells does not determine functional properties (Kelly and Van Essen, 1974; Gilbert and Wiesel, 1979, 1981; Parnavelas et al., 1983; Martin, 1984; Martin and Whitteridge, 1984). Results from the visual cortex of reeler mice, where abnormally shaped and positioned neurons still have basically normal response properties (Dräger, 1981; Simmons and Pearlman, 1983), also argue against the importance of structure in determining functional properties.

\section{Analogies to mammalian retina}

The evidence presented, here, however, which reveals a definite relationship between a pyramidal cell's structure and its efferent target, argues that along some (perhaps as yet undescribed) set of parameters, cellular architecture may relate to functional properties. The important, unresolved issue is whether these different morphological classes, with their distinct targets, have correspondingly different response properties that would reflect their participation in different aspects of cortical processing. In order to evaluate the kinds of differences that might be seen, and the kinds that might not, it is useful to consider some 

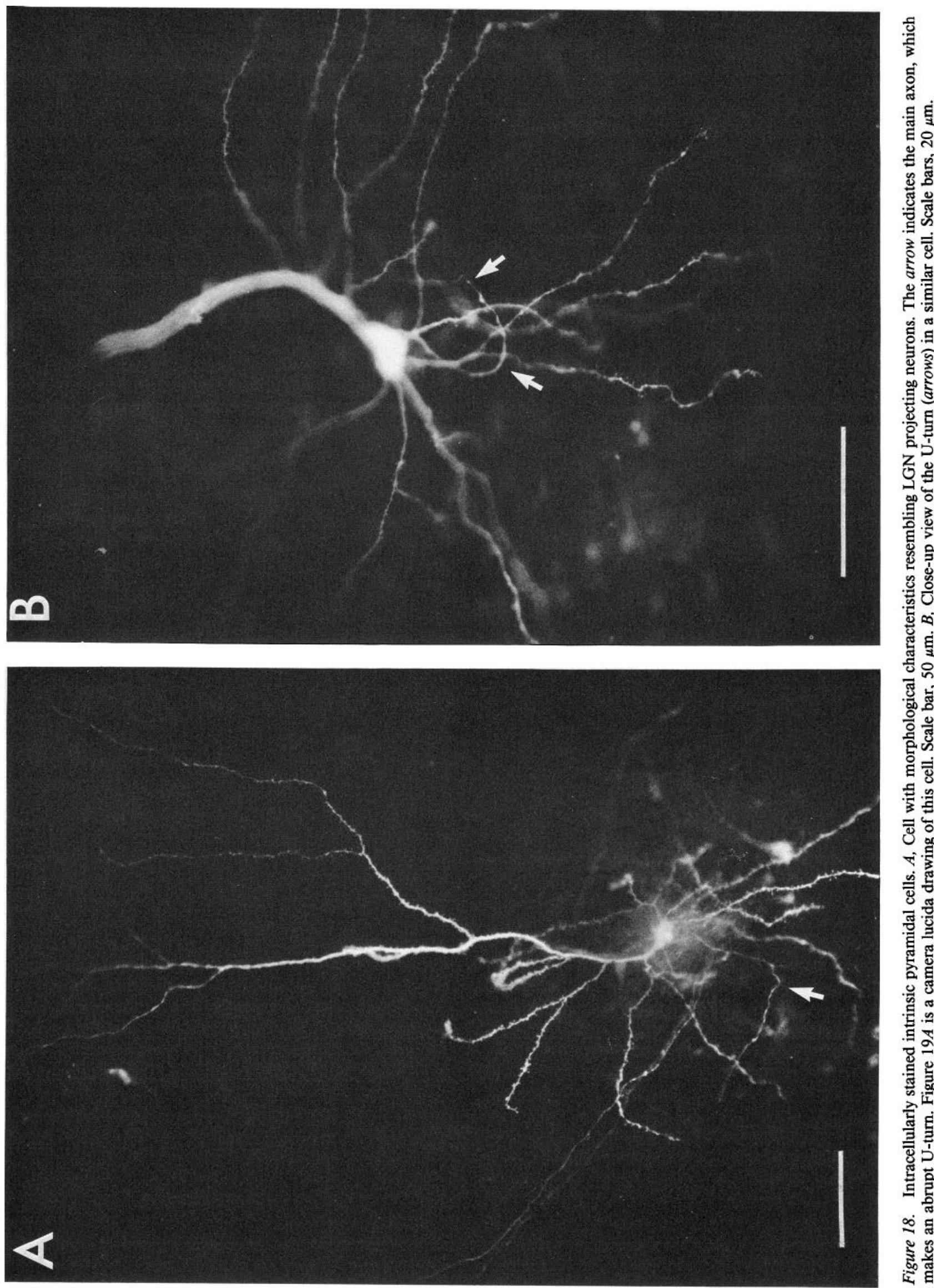
A

B

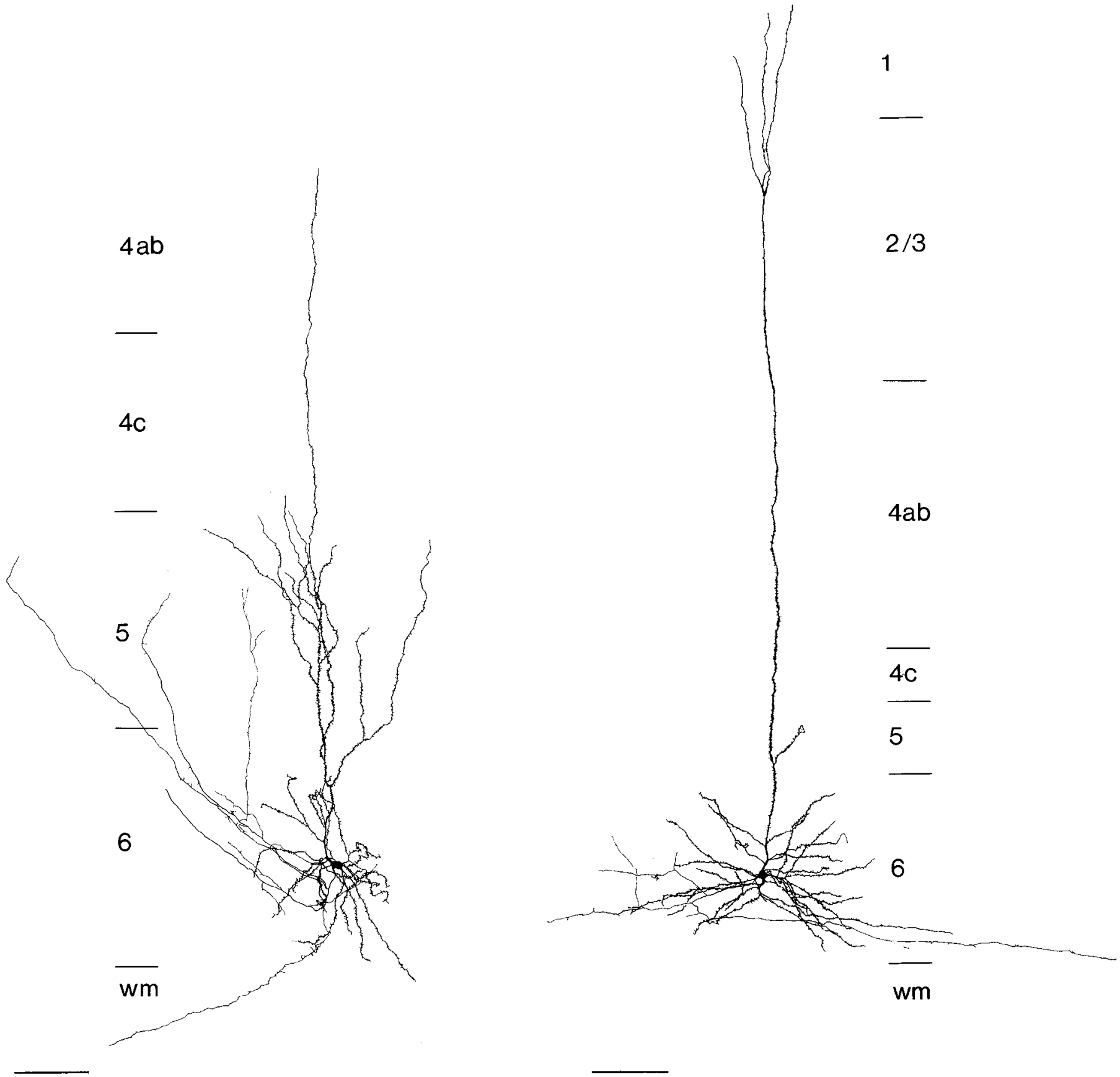

Figure 19. Intrinsic pyramidal cells. $A$, Drawing of the cell in Figure $18 \mathrm{~A}$. A very thin, unmyelinated process enters the white matter but definitely ended where indicated. The thick ascending collaterals could not be followed to their final destination, although some terminals are clearly visible in layer 5. B, Cell with morphological characteristics resembling those of claustrum projecting neurons (compare, for example, Fig. 10). The axon initially heads towards the white matter but then turns and travels horizontally, without entering the white matter, for over $1 \mathrm{~mm}$ (the axon traveled in the direction directly opposite to that of efferent axons that entered the white matter). The axonal arbor, although sparse, has the horizontal orientation and vertical collaterals characteristic of claustrum projecting cells. Scale bars, $100 \mu \mathrm{m}$.

structure-function relationships of retinal ganglion cells in the mammalian retina. The retina, like the striate cortex, is a laminated structure, but one in which it has been possible, for some kinds of ganglion cells, to correlate synaptic inputs, cell morphology, site of projection, and receptive field properties. The response properties of neurons in both layer 6 and the retinal ganglion cell layer are shaped by stratified, layer-specific syn- aptic connections. In the retina, distinctive response properties, such as On versus Off responses, arise from subtle variations in dendritic arbors, not unlike the differences between dendrites of claustrum and LGN projecting neurons. The layer 6 cells and the ganglion cells have dendrites that can (1) arborize the same layer but to different extents or configurations or (2) arborize in layers unoccupied by dendrites of the other cell type. In the 
retina, both mechanisms result in different physiological classes of ganglion cells, and it would be surprising if this were not also true in cortex, given the same sorts of structural differences.

Alpha and beta On-center ganglion cells provide an example of cells whose dendrites are in the same layer but have different geometries. Both have dendritic branches exclusively in sublamina $b$ of the inner plexiform layer. However, alpha cells have dendritic arbors much larger than the restricted arbor of beta cells (Boycott and Wässle, 1974). Furthermore, alpha cells get most of their input from amacrine cells, while beta cells get most of theirs from bipolar cells (Kolb, 1979). Physiologically, alpha cells have larger receptive fields and brisk, transient responses, whereas beta cells have smaller fields and discharge tonically. Thus, although the cell bodies and dendrites of both types share a layer and several important response properties (center-surround receptive fields, On-center responses), their dendrites receive very different synaptic inputs that can produce a spectrum of important physiological differences.

Claustrum and LGN projecting cells also have dendrites in the same layers that show significant differences in number and arrangement. The basal dendrites of claustrum projecting cells are consistently longer, sparser, and elongated within layer 6 , in contrast to the shorter, dense, more symmetrically organized basal dendrites of LGN projecting cells. The apical dendrites of both cell types have branches in layer 5 , but those of type I LGN projecting cells spread more widely than claustrum projecting neurons. A major source of input to layer 5 is the collaterals of pyramidal cells in layer $2 / 3$ (Gilbert and Wiesel, 1981). Although the source of input onto the apical dendrites of layer 6 cells is unknown, LGN projecting cells can apparently sample inputs from a much larger region of cortex. The largest of these cells, with apical dendrites spreading $800 \mu \mathrm{m}$ in layer 5 , could easily cover 2 ocular dominance columns and integrate inputs from both eyes. If retinal ganglion cell morphology provides an interpretive guide, then differences in dendrite number and density within layers 6 and 5 should reflect underlying differences in the receptive fields of each cell type.

As both the inputs to and outputs from striate cortex are laminated, if one cell type has dendrites in a layer in which another type does not, this must reflect differences in synaptic input. In the retina, differences in the sublaminar position of dendritic arbors distinguish On- from Off-center alpha ganglion cells (Famiglietti and Kolb, 1976). The dendrites of claustrum and geniculate projecting cells also arborize in different layers. The apical dendrites of LGN cells have numerous branches in layer 4 , but those of claustrum projecting cells avoiding arborizing within it (although thcir apical dendrites pass through layer 4). Therefore, LGN projecting cells cannot receive monosynaptic input from layers 1 and 2 , whereas claustrum projecting cells, via their apical dendrites, can. However, LGN projecting cells, with widespread apical dendrites in layer 4 , could receive considerably greater monosynaptic input from both geniculocortical afferents and collaterals of other LGN projecting cells (McGuire et al., 1984).

\section{Claustrum and LGN projecting neurons: possible physiological differences}

Although analogies with the retina suggest that dendritic patterns in cortex can correlate with differences in synaptic input and receptive fields, predicting physiological differences solely on the basis of morphology is presently impossible. In each cortical layer most neurons share the most obvious receptive field properties. In layer 6, many cells have very long receptive fields; unlike cortical neurons in other layers, they respond well to long bars (Gilbert, 1977). Perhaps this property results from shared kinds of inputs onto similar portions of dendrites. The anatomical results described here suggest that careful comparison of the receptive field properties of 2 identified populations physiologically may reveal significant differences. So far, studies aimcd at isolating a unique response property of a projectiondefined cell type have compared the properties of cells with an identified connection in the properties of the rest of the layer's population (e.g., Palmer and Rosenquist, 1974; Toyama et al., 1974; Singer et al., 1975; Albus and Donate-Oliver, 1977; Gilbert, 1977; Harvey, 1978), rather than with a second defined projection originating from the same layer. When LGN projecting cells were identified by antidromic activation, most (or possibly all) were simple cells with the long receptive fields characteristic of layer 6 (Gilbert, 1977; Ferster and Lindström, 1983). Comparable studies on claustrum projecting cells are lacking. Cells in the claustrum itself are well-oriented and have receptive field properties similar to cortical neurons (Sherk and LeVay, 1981) but are distinguished by their long receptive fields, which are similar to layer 6 cells. Examination of 10 physiologically characterized, intracellularly injected layer 6 cells (C. D. Gilbert and T. N. Wiesel, personal communication), which included 2 cells resembling claustrum projecting cells, also failed to demonstrate an obvious difference in the physiological properties of the 2 cell types. However, it seems likely that a direct examination of this question, especially a more complete description of the properties of claustrum projecting cells, would reveal some important physiological difference and provide insight into the role played by particular dendritic structures in cortical receptive field architecture.

Unlike retinal ganglion cells, cortical pyramidal neurons have local axonal collaterals that arborize in specific laminae. Thus, a pyramidal cell provides both the output from, and part of the input to, a local circuit and can create or modify the responses of other cells within and outside its "home" lamina. The differences in the intrinsic axon arbors of claustrum and geniculate projecting cells are dramatic and consistent, and demonstrate that these 2 groups not only receive input from different local circuits, but provide input to different circuits as well. Even if both cells had identical dendritic arbors (which they do not) and identical response properties (which seems unlikely), axonal arborizations alone demonstrate that they must play different roles in cortical processing. The results of several recent experiments suggest that, consistent with the morphological differences described here, geniculate and claustrum projecting neurons mediate distinct modifications of striate neuron receptive field properties.

Recently, Bolz and Gilbert (1986) showed that reversibly inactivating small portions of layer 6 by local GABA application removed the end-inhibition in all cells in corresponding portions of the upper layers, leaving other response properties unchanged. These results strongly implicate the layer 6 to 4 connection, which originates primarily from geniculate projecting cells, in generating the specific property of end-inhibition.

The role of the corticoclaustral loop is less clear. Ablating the claustrum by kainic acid injections reportedly led to a reduction in the number of end-inhibited cells encountered (Sherk and LeVay, 1983). The blocking experiments of Bolz and Gilbert cannot unambiguously assess the relative contributions of the claustral loop and the layer 6-4 connection in generating end- 
inhibition, since locally blocking layer 6 will block a portion of the corticoclaustral loop as well. Boyapati and Henry (1985) claim that, compared to the cortical population as a whole, cells in layers 6 and 4 that receive claustral input had either weak end-inhibition or lacked it entirely. Although the role of the corticoclaustral loop remains obscure, it seems more likely that end-inhibition is generated by the intrinsic axons of LGN projecting cells, and not by the layer 6 restricted collaterals of claustrum projecting cells. However, the extensive horizontal collaterals of claustrum projecting cells could help construct the long receptive fields in some layer 6 cells.

\section{Synaptic relationships between identified projection neurons}

How independent are these 2 systems? Explicitly, how much can one system influence the other in generating or modifying response properties? Both claustrum and LGN projecting cells have common features: most have oriented receptive fields, at least some of both have long receptive fields, and both probably receive direct geniculate input within layer 6 (Ferster and Lindström, 1983). The morphology of the 2 intrinsic axon systems places several constraints on interactions between the populations and suggests that their respective response properties are generated by parallel, rather than serial, interactions. In particular, geniculate projecting cells showed a consistent paucity of collaterals within layer 6 . This demonstrates that, while these cells can generate end-inhibition within layer 4 , they generally have little effect on either other LGN projecting cells or on claustrum projecting neurons. On physiological grounds, Ferster and Lindström (1983) reached a similar conclusion. The extensive horizontal connections within layer 6 of claustrum projecting cells provide a possible avenue for information transfer from one population to another; hence, if direct connections exist between claustrum and LGN projecting populations, information flows primarily in that direction within layer 6 . Within layer 4 it is possible that the collaterals of LGN projecting cells could contact the apical dendrites of claustrum projecting cells, since some make contact onto spine-bearing processes (McGuire et al., 1984).

\section{What constitutes a target for pyramidal cells?}

If each projection-defined group of pyramidal cells has synaptic connections that are largcly different from other cells in the same layer, analysis of individual circuits would be greatly simplified. It should be possible, for example, to work backwards from the output neuron to determine the distribution and sources of its inputs. In order to make this framework usable, 2 important questions must be addressed. First, at what level of resolution is a "target" defined? For instance, is the LGN as a whole a single target? Or does each lamina (or even different cells within a geniculate lamina) constitute an independent target? Second, how generalizable are results obtained in layer 6 of cat striate cortex to other cortical laminae and to other species?

Several observations suggest that the claustrum is functionally and anatomically quite uniform. The claustrum has a single retinotopic map, and cells within the nucleus apparently have very similar response properties (LeVay and Sherk, 1981 b; Sherk and LeVay, 1981). Anatomically, only 2 cell types have been described, a spiny projection neuron and an aspinous, local circuit cell, both of which receive cortical afferents (LeVay and Sherk, 1981a). This target uniformity matches the morphological homogeneity of layer 6 claustrum projecting cells.

The morphology of geniculate projecting cells was more vari- able than that of the claustrum projecting neurons. Unlike the claustrum, the LGN is not a functionally uniform target. Separate geniculate laminae subserve each eye, and perhaps more importantly, 3 functionally and anatomically distinct parallel pathways - the $\mathrm{X}, \mathrm{Y}$, and $\mathrm{W}$ systems-are relayed through it (reviewed in Lennie, 1980). The variability in the diameters of the axons of LGN projecting cells suggests a possible relationship to these afferent subsystems. $X, Y$, and $W$ axons cover almost a 3-fold range of axon diameters (Ferster and LeVay, 1978), which is very similar to the range of axons from LGN projecting cells. A distinct type of LGN projecting neuron could therefore be associated with each afferent pathway, suggesting a further possible target-specific differentiation of the corticothalamic pathway.

Could the relatively simple rule that a specific type of pyramidal cell is uniquely associated with each projection account for diversity of pyramidal cell types? The upper layers of V1 in the monkey have projections to at least 4 other well-defined visual areas; some (like the LGN and V2) may consist of more than one functional target (Van Essen, 1985). Similarly, area 17 in the cat projects to upwards of 7 extrastriate areas, with most projections originating from layer $2 / 3$. Since a pyramidal cell generally projects to a single target (e.g., Andersen et al., 1985; DeYoe and Van Essen, 1985), the number of projections could account for a wide variety of pyramidal cells. The methodology described in this report should make testing this hypothesis quite feasible.

\section{Nonprojecting pyramidal cells in layer 6: possible origins}

However, the relationship of at least 1 variety of pyramidal cell to a specific efferent projection is not immediately apparent, namely, the considerable population of layer 6 pyramidal cells without efferent axons. Although isolated examples of nonprojecting pyramidal cells have been described (Sholl, 1955; Valverde, 1986), they comprise an unexpectedly large proportion of layer 6 cells. Technical limitations imposed by Golgi and intracellular staining are probably responsible for underestimating this population. In Golgi staining, the lack of an axon, especially in adult animals, can result from failure to obtain complete axonal impregnation, a known artifact. With intracellular staining, pyramidal cells without efferent axons have also been observed, but sample numbers are too small to estimate their overall frequency reliably (Gilbert and Wiesel, 1983). In the experiments described here, neither incomplete filling nor small sample size are tenable explanations for the large numbers of "intrinsic" pyramidal cells.

The lack of an efferent axon in these cells is probably not an artifact. Cells without an efferent axon never contained retrogradely transported microspheres. This argues against the interpretation that the axon either disappeared as a result of the slicing procedure or that the intracellular Lucifer yellow failed to visualize it. In either case, at least some cells without an efferent axon should have contained retrograde label. A more likely explanation is that these cells represent either neurons whose axons never reached the white matter or cells that originally made efferent connections but lost them sometime during development. A number of studies on cortical development provide indirect evidence for the latter possibility. In young animals, cortical cells make considerably more extensive efferent projections than they do in the adult (Innocenti and Caminiti, 1980; O'Leary et al., 1981; Ivy and Killackey, 1982; Price and Blakemore, 1985; Killackey and Chalupa, 1986). Many cells 
that lose an efferent axon survive into adulthood (O'Leary et al., 1981). In the rat, some cells that have lost one projection either make or maintain other efferent projections (Ivy and Killackey, 1982), but whether others may end up completely without efferent axons is unknown.

The significant proportion of intrinsic pyramidal cells, and their morphological resemblance to either geniculate or claustrum projecting neurons, suggests that these cells originally projected to one of these targets (or perhaps across the corpus callosum) but retracted their axons somctime during development. If this population represents the outcome of the elimination of exuberant connections, then cells without an efferent axon should be common in other cortical layers. At least one such pyramidal cell has been described in cat layer 2, which despite having intrinsic axon collaterals over $4 \mathrm{~mm}$ long had no efferent axon (Gilbert and Wiesel, 1983).

\section{Intrinsic and extrinsic influences on neuronal phenotype}

These neurons raise several related questions of how neurons acquire a specific set of morphological characteristics. Do different neuronal classes have an innate program that dictates both form and extrinsic connections? Does a neuron's projection trigger differentiation along a particular route or does a cell's local environment shape its final form? Understanding the developmental history of intrinsic pyramidal cells could help sort out some of the possibilities. For instance, if these cells never reached an efferent target, yet differentiated into cell types recognizable as geniculate or claustrum projecting, this would provide strong evidence that a target structure is not required for phenotypic development, implying that a combination of genetic programs and local environmental influences (for example, afferent input) dictate neuronal form. Almost no data are available on the instructional role of target structures in defining cortical neuronal phenotypes. In the grasshopper, Whitington et al. (1982) concluded that at least some types of cells could undergo normal dendritic differentiation even if prevented from reaching their efferent target.

Both claustrum and LGN projecting cells occupy similar laminar positions and therefore have potential access to similar environmental influences. Nonetheless, they show nongraded, nonoverlapping patterns of dendrites and axons. This suggests innate differences between these cell types, either in their developmental programs or in their response to environmental cues, rather than late differentiation from a common precursor.

One innate difference that could determine either efferent projection or final morphology is cell birthdate. In the monkey, time of birth apparently plays a role in organizing efferent projections: The first neurons to reach their final position in layer 6 send the first axons into the magnocellular portions of the LGN; the projection to the parvicellular layers originates later, from a second group of neurons in layer 6 born after the first (Shatz and Rakic, 1981). These projection differences also correlate with morphological differences (Lund and Boothe, 1975). However, the fact that claustrum and LGN projecting cells occupy overlapping horizontal positions in layer 6 means that some of each of these projection classes must have been generated and migrated to cortex at roughly the same time (Rakic, 1974; Luskin and Shatz, 1985). Nevertheless, slight differences in birthdates between the 2 classes or different states of differentiation of their postsynaptic targets could underlie the generation of distinct cell types.

Because the claustrum projection consists of relatively few cells (probably fewer than 150,000 in striate cortex) and because they have such uniform morphological characteristics, they could conceivably be clonally derived from a relatively small number of precursor cells. There is considerable evidence that such a mechanism generates Purkinje cells (another uniform cell type) in the cerebellum (Wetts and Herrup, 1982). Tissue culture studies of neuroblastoma cells also show that mitotically related cells have much more similar neurite patterns than unrelated cells (Solomon, 1979). A clonal relationship between cells might provide a mechanism for generating a morphologically uniform cell class that could contact a particular efferent target.

\section{References}

Albus, K., and F. Donate-Oliver (1977) Cells of origin of the occipitopontine projection in the cat: Functional properties and intracortical location. Exp. Brain Res. 28: 167-174.

Andersen, R. A., C. Asanuma, and W. M. Cowan (1985) Callosal and prefrontal associational projecting cell populations in area $7 \mathrm{~A}$ of the macaque monkey: A study using retrogradely transported fluorescent dyes. J. Comp. Neurol. 232: 443-455.

Baughman, R. W., and C. D. Gilbert (1981) Aspartate and glutamate as possible neurotransmitters in the visual cortex. J. Neurosci. $1: 427-$ 439.

Bolz, J., and C. D. Gilbert (1986) Generation of end-inhibition in the visual cortex via interlaminar connections. Nature 320: 362-365.

Boyapati, J., and G. H. Henry (1985) The character and influence of the claustral pathway to the striate cortex of the cat. Exp. Brain Res. 61: 141-152.

Boycott, B. B., and H. Wässle (1974) The morphological types of ganglion cells of the domestic cat's retina. J. Physiol. (Lond.) 240: $397-419$.

DeYoe, E. A., and D. C. Van Essen (1985) Segregation of efferent connections and receptive field properties in visual area V2 of the macaque. Nature 317: 58-61.

Dräger, U. C. (1981) Observations on the organization of the visual cortex in the reeler mouse. J. Comp. Neurol. 201: 555-570.

Famiglietti, E. V. Jr., and H. Kolb (1976) Structural basis for ONand OFF-center responses in retinal ganglion cells. Science 194: 193195.

Ferster, D., and S. LeVay (1978) The axonal arborization of lateral geniculate neurons in the striate cortex of the cat. J. Comp. Neurol. 182: 923-944.

Ferster, D., and S. Lindström (1983) An intracellular analysis of geniculo-cortical and intracortical conncctivity in area 17 of the cat. $J$. Physiol. (Lond.) 342: 181-216.

Gilbert, C. D. (1977) Laminar differences in receptive field properties in cat primary visual cortex. J. Physiol. (Lond.) 268: 391-421.

Gilbert, C. D. (1983) Microcircuitry of the visual cortex. Annu. Rev. Neurosci. 6: 217-247.

Gilbert, C. D., and J. P. Kelly (1975) The projections of cells in different layers of the cat's visual cortex. J. Comp. Neurol. 163: 81106.

Gilbert, C. D., and T. N. Wiesel (1979) Morphology and intracortical projections of functionally identified neurons in cat visual cortex. Nature 280: 120-125.

Gilbert, C. D., and T. N. Wiesel (1981) Laminar specializations and intracortical connections in cat primary visual cortex. In The Organization of the Cerebral Cortex, F. O. Schmitt, F. G. Worden, G. Adelman, and S. G. Dennis, eds., pp. 163-191, MIT Press, Cambridge, MA.

Gilbert, C. D., and T. N. Wiesel (1983) Clustered intrinsic connections in cat visual cortex. J. Neurosci. 3: 1116-1133.

Gupta, R. K., B. M. Salzberg, A. Grinvald, L. B. Cohen, K. Kamino, S. Lesher, M. B. Boyle, A. S. Waggoner, and C. H. Wang (1981) Improvements in optical methods for measuring rapid changes in membrane potential. J. Membr. Biol. 58: 123-137.

Harvey, A. R. (1978) Characteristics of corticothalamic neurons in area 17 of the cat. Neurosci. Lett. 7: 177-181.

Harvey, A. R. (1980) A physiological analysis of subcortical and commissural projections of areas 17 and 18 of the cat. J. Physiol. (Lond.) 302: 507-534. 
Hatton, G. I., A. B. Doran, A. K. Salm, and K. D. Tweedle (1980) Brain slice preparation: Hypothalamus. Brain Res. Bull. 5: 405-414.

Henry, G. H., A. R. Harvey, and J. S. Lund (1979) The afferent connections and laminar distribution of cells in the cat striate cortex. J. Comp. Neurol. 187: 725-744.

Hubel, D. H., and T. N. Wiesel (1962) Receptive fields, binocular interaction and functional architecture in the cat's visual cortex. $\mathrm{J}$. Physiol. (Lond.) 160: 106-154.

Hudspeth, A. J., and D. P. Corey (1978) Controlled bending of highresistance glass micropipettes. Am. J. Physiol. 234: C56-C57.

Innocenti, G. M., and R. Caminiti (1980) Postnatal shaping of callosal connections from sensory areas. Exp. Brain Res. 38: 381-394.

Ivy, G. O., and H. P. Killackey (1982) Ontogenetic changes in the projections of neocortical neurons. J. Neurosci. 2: 735-743.

Jones, E. G. (1975) Varieties and distribution of non-pyramidal cells in the somatic sensory cortex of the squirrel monkey. J. Comp. Neurol. 160: 205-268.

Katz, L. C., A. Burkhalter, and W. J. Dreyer (1984) Fluorescent latex microspheres as a retrograde neuronal marker for in vivo and in vitro studies of visual cortex. Nature 310: 498-500.

Kelly, J. P., and D. C. Van Essen (1974) Cell structure and function in the visual cortex of the cat. J. Physiol. (Lond.) 328: 51 5-547.

Killackey, H. P., and L. M. Chalupa (1986) Ontogenetic change in the distribution of callosal projection neurons in the postcentral gyrus of the fetal rhesus monkey. J. Comp. Neurol. 244: 331-348.

Kolb, H. (1979) The inner plexiform layer in the retina of the cat: Electron microscopic observation. J. Neurocytol. 8: 295-329.

Lennie, P. (1980) Parallel visual pathways: A review. Vision Res. 20 561-594.

LeVay, S. (1973) Synaptic patterns in the visual cortex of the cat and monkey. Electron microscopy of Golgi preparations. J. Comp. Neurol 150: 53-86.

LeVay, S., and S. K. McConnell (1982) On and off layers in the latera geniculate nucleus of the mink. Nature 300:350-351.

LeVay, S., and H. Sherk (1981a) The visual claustrum of the cat. I. Structure and connections. J. Neurosci. 1: 956-980.

LeVay, S., and H. Sherk (1981b) The visual claustrum of the cat. II. The visual field map. J. Neurosci. 1: 981-992.

Leventhal, A. G., and H. V. B. Hirsch (1978) Receptive field properties of neurons in different laminae of visual cortex of the cat. J. Neurophysiol. 41: 948-962.

Livingstone, M. S., and D. H. Hubel (1983) Specificity of corticocortical connections in monkey visual system. Nature 304: 531-534.

Livingstone, M. S., and D. H. Hubel (1984a) Anatomy and physiology of a color system in the primate visual cortex. J. Neurosci. 4: 309356.

Livingstone, M. S., and D. H. Hubel (1984b) Specificity of intrinsic connections in primate primary visual cortex. J. Neurosci. 2: 2830 2835 .

Lorente de Nó, R. (1933) Studies on the structure of the cerebral cortex J. Psychol. Neurol. 45: 382-438.

Lund, J. S. (1973) Organization of neurons in the visual cortex, area 17, of the monkey (Macaca mulatta). J. Comp. Neurol. 147: 455496.

Lund, J. S. (1981) Intrinsic organization of the primate visual cortex, area 17, as seen in Golgi preparations. In The Organization of $\mathrm{Ce}$ rebral Cortex, F. O. Schmitt, F. G. Worden, G. Adelman, and S. G. Dennis, eds., pp. 325-345, MIT Press, Cambridge.

Lund, J. S., and R. G. Boothe (1975) Interlaminar connections and pyramidal ncuron organization in the visual cortex, area 17 , of the macaque monkey. J. Comp. Neurol. 159: 305-334.

Lund, J. S., G. H. Henry, C. I. Macqueer, and A. R. Harvey (1979) Anatomical organization of the primary visual cortex (area 17) of the cat. A comparison with area 17 of the macaque monkey. J. Comp. Neurol. 184: 599-618

Lund, J. S., D. Fitzpatrick, and A. L. Humphrey (1985) The striate visual cortex of the tree shrew. In Cerebral Cortex, Vol. 3, A. Peters and E. G. Jones, eds., pp. 157-205, Plenum, New York.

Luskin, M. B., and C. J. Shatz (1985) Studies of the earliest generated cells of the cat's visual cortex: Cogeneration of subplate and marginal zones. J. Neurosci. 5: 1062-1075.

McGuire, B. A., J. P. Hornung, C. D. Gilbert, and T. N. Wiesel (1984) Patterns of synaptic input to layer 4 of the cat striate cortex. J. Neurosci. 4: 3021-3033.
Martin, K. A. C. (1984) Neuronal circuits in cat striate cortex. In Cerebral Cortex, Vol. 2, E. G. Jones and A. Peters, eds., pp. 241284, Plenum, New York.

Martin, K. A. C., and D. Whitteridge (1984) Form, function and intracortical projections of spiny neurons in the striate cortex of the cat. J. Physiol. (Lond.) 353: 463-504.

Miller, J. P., and A. I. Selverston (1979) Rapid killing of single neurons by irradiation of intracellularly injected dye. Science 206: 702-704.

O'Leary, D. D. M., B. B. Stanfield, and W. M. Cowan (1981) Evidence that the early postnatal restriction of the cells of origin of the callosal projection is due to the elimination of axonal collaterals rather than to the death of neurons. Dev. Brain Res. 1: 607-617.

O'Leary, J. L. (1941) Structure of the area striata in the cat. J. Comp. Neurol. 75: 131-164.

Otsuka, R., and H. Hassler (1962) Uber Aufbau und Gliederung der corticalen Sehsphare bei der Katze. Arch. Psych. Nevenkr. 203: 212234.

Palmer, L. A., and A. C. Rosenquist (1974) Visual receptive ficlds of single striate cortical units projecting to the superior colliculus in the cat. Brain Res. 67: 27-42.

Parnavelas, J. G., R. A. Burne, and C.-S. Lin (1983) Distribution and morphology of functionally identified neurons in the visual cortex of the rat. Brain Res. 261: 21-29.

Price, D. J., and C. Blakemore (1985) The postnatal development of the association projection from visual cortical area 17 to area 18 in the cat. J. Neurosci. 5: 2443-2452.

Rakic, P. (1974) Neurons in rhesus monkey visual cortex: Systematic relation between time of origin and eventual disposition. Science 183 : 425-427.

Ramon y Cajal, S. (1911) Histologie du Système Nerveux de l'Homme et des Vertèbres (1972 ed.), CSIC, Madrid.

Roscnquist, A. C. (1985) Connections of visual cortical areas in the cat. In Cerebral Cortex, Vol. 3, A. Peters and E. G. Jones, eds., pp. 81-117, Plenum, New York.

Sanderson, K. J. (1971) The projection of the visual field to the lateral geniculate and medial interlaminar nuclei in the cat. J. Comp. Neurol. 143: $101-118$

Shatz, C. J., and P. Rakic (1981) The genesis of efferent connections from the visual cortex of the fetal rhesus monkey. J. Comp. Neurol. 196: 287-307.

Sherk, H., and S. LeVay (1981) The visual claustrum of the cat. III. Receptive field properties. J. Neurosci. 1: 993-1002.

Sherk, H., and S. LeVay (1983) Contribution of the cortico-claustral loop to receptive field properties in area 17 of the cat. J. Neurosci. 3: 2121-2127.

Sholl, D. A. (1955) The organization of the visual cortex in the cat J. Anat. 89: 33-46.

Simmons, P. A., and A. L. Pearlman (1983) Receptive-field properties of transcallosal visual cortical neurons in the normal and reeler mouse. J. Neurophysiol. 50: 838-847.

Singer, W., F. Tretter, and M. Cynader (1975) Organization of cat striate cortex: A correlation of receptive field properties with afferent and efferent connections. J. Neurophysiol. 38: 1080-1098.

Solomon, F. (1979) Detailed neurite morphologies of sister neuroblastoma cells are related. Cell 16: 165-169.

Stewart, W. W. (1978) Functional connections between cells as revealed by dye-coupling with a highly fluorescent Naphthalimide tracer. Cell 14: 741-759.

Toyama, K., K. Matsunami, T. Ohno, and S. Tokashiki (1974) An intracellular study of neuronal organization in the visual cortex. Exp. Brain Res. 21: 45-66.

Tsumoto, T., and K. Suda (1980) Three groups of cortico-geniculate neurons and their distribution in binocular and monocular segments of cat striate cortex. J. Comp. Neurol. 193: 223-236.

Tsumoto, T., O. D. Creutzfeldt, and C. R. Legendy (1978) Functional organization of the corticofugal system from visual cortex to lateral geniculate nucleus in the cat. Exp. Brain Res. 32: 345-364.

Tusa, R. J., L. A. Palmer, and A. C. Rosenquist (1981) Multiple cortical visual areas: Visual field topography in the cat. In Cortical Sensory Organization, Vol. 2, C. N. Woolsey, ed., pp. 1-31, Humana, Clifton, NJ.

Valverde, F. (1986) Intrinsic neocortical organization: Some comparative aspects. Neuroscience 18: 1-23.

Van Essen, D. C. (1985) Functional organization of primate visual 
cortex. In Cerebral Cortex, Vol. 3, A. Peters and E. G. Jones, eds., pp. 259-329, Plenum, New York.

Wetts, R., and K. Herrup (1982) Cerebellar Purkinje cells are descended from a small number of progenitors committed during early development: Quantitative analysis of lurcher chimeric mice. J. Neurosci. 2: 1494-1498.
Whitington, P. M., M. Bate, E. Seifert, K. Ridge, and C. S. Goodman (1982) Survival and differentiation of identified embryonic neurons in the absence of their target muscles. Science 215: 973-975. 